\title{
Usher Syndrome: Genetics of a Human Ciliopathy
}

\author{
Carla Fuster-García 1,2,3,+D, Belén García-Bohórquez ${ }^{1,2,+}{ }^{+}$, Ana Rodríguez-Muñoz 1,2 , Elena Aller 1,2,3,4 , \\ Teresa Jaijo 1,2,3,4 , José M. Millán 1,2,3,*(D) and Gema García-García 1,2,3
}

1 Molecular, Cellular and Genomics Biomedicine Research Group, Instituto de Investigación Sanitaria La Fe (IIS La Fe), 46026 Valencia, Spain; c.fustergarcia@gmail.com (C.F.-G.); belen_garcia@iislafe.es (B.G.-B.); rodriguezmunoz.ana@gmail.com (A.R.-M.); aller_ele@gva.es (E.A.); jaijo_ter@gva.es (T.J.); gegarcia@ciberer.es (G.G.-G.)

2 Unidad Mixta de Enfermedades Raras IIS La Fe-Centro de Investigación Príncipe Felipe, 46026 Valencia, Spain

3 Biomedical Research Network for Rare Diseases, Hospital Universitario y Politécnico La Fe, 46026 Valencia, Spain

4 Genetics Unit, Hospital Universitario y Politécnico La Fe, 46026 Valencia, Spain

* Correspondence: millan_jos@gva.es

+ These authors have contributed equally to this work and share first authorship.

check for updates

Citation: Fuster-García, C.;

García-Bohórquez, B.;

Rodríguez-Muñoz, A.; Aller, E.; Jaijo,

T.; Millán, J.M.; García-García, G.

Usher Syndrome: Genetics of a

Human Ciliopathy. Int. J. Mol. Sci.

2021, 22, 6723. https://doi.org/

$10.3390 /$ ijms 22136723

Academic Editors: Tamar Ben-Yosef and Susanne Roosing

Received: 31 May 2021

Accepted: 16 June 2021

Published: 23 June 2021

Publisher's Note: MDPI stays neutral with regard to jurisdictional claims in published maps and institutional affiliations.

Copyright: (C) 2021 by the authors. Licensee MDPI, Basel, Switzerland. This article is an open access article distributed under the terms and conditions of the Creative Commons Attribution (CC BY) license (https:// creativecommons.org/licenses/by/ $4.0 /)$.

\begin{abstract}
Usher syndrome (USH) is an autosomal recessive syndromic ciliopathy characterized by sensorineural hearing loss, retinitis pigmentosa and, sometimes, vestibular dysfunction. There are three clinical types depending on the severity and age of onset of the symptoms; in addition, ten genes are reported to be causative of USH, and six more related to the disease. These genes encode proteins of a diverse nature, which interact and form a dynamic protein network called the "Usher interactome". In the organ of Corti, the USH proteins are essential for the correct development and maintenance of the structure and cohesion of the stereocilia. In the retina, the USH protein network is principally located in the periciliary region of the photoreceptors, and plays an important role in the maintenance of the periciliary structure and the trafficking of molecules between the inner and the outer segments of photoreceptors. Even though some genes are clearly involved in the syndrome, others are controversial. Moreover, expression of some USH genes has been detected in other tissues, which could explain their involvement in additional mild comorbidities. In this paper, we review the genetics of Usher syndrome and the spectrum of mutations in USH genes. The aim is to identify possible mutation associations with the disease and provide an updated genotype-phenotype correlation.
\end{abstract}

Keywords: deafblindness; inherited retinal dystrophy; retinitis pigmentosa; sensorineural hearing loss; inner ear; photoreceptor; variant curation; pathogenic variant

\section{Introduction}

Usher syndrome (USH) is the most common cause of genetic deafblindness and follows an autosomal recessive inheritance. This disorder is characterized by the combination of a degenerative vision loss condition known as retinitis pigmentosa (RP), sensorineural hearing loss (SNHL) and, sometimes, vestibular dysfunction. USH is considered a rare disease, because it has a low prevalence, which ranges from 3 to 6.2 per 100,000 people [1]. Even though a recent report has cast doubts about the vestibular phenotypic differences among the USH subtypes [2], this disease is traditionally classified into three different subtypes depending on the age of onset, severity and progression of the symptoms, and the presence or absence of vestibular dysfunction [3]. USH type 1 (USH1) is the most severe subtype and is characterized by a severe to profound prelingual SNHL, early RP onset and vestibular alterations. USH type 2 (USH2) is the most frequent subtype and presents with moderate to severe SNHL, onset of RP in the second decade of life, and normal vestibular function. USH type 3 (USH3) is the rarest form and is characterized by 
postlingual progressive $\mathrm{SNHL}$, and both a variable onset age of RP and vestibular function. Some patients do not fit into these three subtypes and are classified as atypical USH. Due to the increased use of high-throughput sequencing (HTS) as the preferred molecular diagnosis tool for USH, and for other retinal dystrophies and hearing loss (HL) disorders, new reports have been published regarding candidate genes, revised genotype-phenotype correlations and insights into the phenotypic spectrum of the disease. In this review, we gather past knowledge and new genetic and clinical findings to provide an updated picture of the current state of USH.

\section{The Genetic Heterogeneity of USH}

In addition to being clinically heterogeneous, USH is also genetically heterogeneous. To date, 10 genes have been associated with USH (Table 1), and these are typically responsible for one of its three subtypes. MYO7A, USH1C, CDH23, PCDH15, USH1G and CIB2 cause USH1; USH2A, ADGRV1 and WHRN are accountable for USH2; and CLRN1 is the only gene associated with USH3 thus far. Moreover, some of these genes are also involved in other non-syndromic pathologies. Mutations in USH1C, CDH23, PCDH15, USH1G, CIB2, WHRN, PDZD7 and MYO7A can cause non-syndromic recessive HL [4-12], and the latter is also associated with a dominant form of HL [13]. In addition, USH2A and CLRN1 are also related to non-syndromic RP $[14,15]$.

Table 1. Summary of the USH genes.

\begin{tabular}{|c|c|c|c|c|c|}
\hline USH Type & Gene & MIM Number & Protein & GRCh38 Coordinates & Function \\
\hline \multirow{6}{*}{ USH1 } & MYO7A & $\begin{array}{l}276900^{1} \\
276903^{2}\end{array}$ & myosin VIIA & chr11:77128246-77215241 & $\begin{array}{c}\text { actin-based motor } \\
\text { protein }\end{array}$ \\
\hline & USH1C & $\begin{array}{l}276904^{1} \\
605242^{2}\end{array}$ & harmonin & chr11:17493895-17544416 & scaffold protein \\
\hline & $\mathrm{CDH} 23$ & $\begin{array}{l}601067^{1} \\
605516^{2} \\
\end{array}$ & cadherin 23 & chr10:71396934-71815947 & cell adhesion \\
\hline & PCDH15 & $\begin{array}{l}602083^{1} \\
605514^{2}\end{array}$ & protocadherin 15 & chr10:53802771-55627942 & cell adhesion \\
\hline & USH1G & $\begin{array}{l}606943^{1} \\
607696^{2} \\
\end{array}$ & SANS & chr17:74916083-74923256 & scaffold protein \\
\hline & CIB2 & $\begin{array}{l}614869^{1} \\
605564^{2}\end{array}$ & CIB2 & chr15:78104606-78131544 & $\begin{array}{c}\text { calcium and } \\
\text { integrin binding } \\
\text { protein }\end{array}$ \\
\hline \multirow{3}{*}{ USH2 } & USH $2 A$ & $\begin{array}{l}276901^{1} \\
608400^{2}\end{array}$ & usherin & chr1:215622891-216423448 & cell adhesion \\
\hline & $A D G R V 1$ & $\begin{array}{l}605472^{1} \\
602851^{2}\end{array}$ & $\begin{array}{l}\text { adhesion } \mathrm{G} \\
\text { protein-coupled } \\
\text { receptor V1 }\end{array}$ & chr5:90529344-91164437 & $\begin{array}{c}\text { adhesion } G \\
\text { protein-coupled } \\
\text { receptor }\end{array}$ \\
\hline & WHRN & $\begin{array}{l}611383^{1} \\
607928^{2}\end{array}$ & whirlin & chr9:114402080-114505473 & scaffold protein \\
\hline USH3 & CLRN1 & $\begin{array}{l}276902^{1} \\
606397^{2}\end{array}$ & clarin 1 & chr3:150926163-150972999 & $\begin{array}{l}\text { transmembrane } \\
\text { protein }\end{array}$ \\
\hline
\end{tabular}

${ }^{1}$ Phenotype MIM number. ${ }^{2}$ Gene/Locus MIM number.

As mentioned above, USH can be caused by mutations in at least ten genes, and each of these is usually accountable for one specific category of the disease. However, the correlation between gene and phenotype is not entirely rigid. The recent increase in the number of genetically screened cases has revealed that some patients harbor mutations in USH genes usually associated with a different subtype. For example, variants in MYO7A 
and $C D H 23$ have been identified in patients diagnosed with USH2 [16-20], and USH1 and USH3 cases have been found to be caused by mutations in USH2A $[16,17,20]$.

\section{The USH Genes}

\subsection{MYO7A}

$M Y O 7 A$, consisting of 49 exons and encompassing an $87 \mathrm{~kb}$ genomic region, was the first gene to be associated with USH [21,22]. MYO7A is the most prevalent gene among USH1 cases-pathogenic variants in this gene comprise $50 \%$ of the cases included in this subtype [23] - and it is also the second most frequently mutated gene of all USH cases [24]. Moreover, it has been reported that mutations in MYO7A can also cause autosomal dominant and recessive HL and atypical USH [25-27]. MYO7A encodes the myosin VIIA protein [21,22], which is included in the family of the called unconventional myosins, motor proteins that carry out intracellular molecular transport by linking to actin. The major isoform consists of 2215 amino acids [28] and the encoded protein has a motor head domain that interacts with actin, followed by a protein-protein interaction domain and ending in a tail responsible for binding to other cellular proteins [29-32]. Myosin VIIA is expressed in the photoreceptors of the retina, the RPE cells, and the inner ear [33-35]. In the retina, this protein is responsible for transporting opsin from the inner to the outer segments [36,37], whereas in the cochlea its function consists of linking the stereocilia tip links, resulting in the maintenance of the hair bundle unity $[38,39]$.

\subsection{USH1C}

The genomic region of the USH1C gene extends to $51 \mathrm{~kb}$ and contains a total of 28 exons, eight of which having alternative splicing [40,41]. This gene has been described as causative of USH1 and non-syndromic HL [42]. Mutations in coding regions that are alternatively spliced (exons 15 and 22 to 28 ) have been related to non-syndromic HL [43] and mutations in constitutive coding to USH1. However, several studies have also suggested that variants in the alternatively spliced exons could be responsible for atypical USH cases [44,45]. The USH1C gene encodes for the harmonin protein, consisting of 899 amino acids, and a variety of scaffold proteins, all of which contain PDZ domains that are in charge of organizing protein complexes, and binding with USH1 and USH2 proteins in both the inner ear and retina $[41,46,47]$.

\section{3. $\mathrm{CDH} 23$}

$\mathrm{CDH} 23$ is the second most frequently mutated gene in USH1 cases and has also been associated with non-syndromic autosomal recessive HL [48]. Missense mutations that allow a residual protein function to be maintained that is sufficient for the correct retina function have been predominantly related to $\mathrm{HL}$, whereas truncating variants are responsible for USH1 [49-52]. This gene encompasses a $300 \mathrm{~kb}$ genomic sequence that has a coding region of 69 exons and two microexons of solely 6 and $3 \mathrm{bp}$. Three different isoforms are encoded by $\mathrm{CDH} 23$ : isoform a contains 3354 amino acids and is the longest, with a total of 27 extracellular $\mathrm{Ca}^{2+}$-binding domains, which differentiates it from isoform $\mathrm{b}$, that has only seven, and $\mathrm{c}$, that has none. Both $\mathrm{a}$ and $\mathrm{b}$ isoforms are in charge of binding the stereocilia through a tip link in unison with protocadherin 15 in the inner ear. They also play a role in shaping the outer segment as a result of its expression in the inner and outer segment, and in the calyceal processes [53-55]. Contrary to the latter two isoforms, and due to the absence of extracellular $\mathrm{Ca}^{2+}$-binding domains, isoform $\mathrm{c}$ is a cytoplasmic protein that manages the microtubule network settlement [56].

\section{4. $\mathrm{PCDH15}$}

The PCDH15 gene, which comprises a genomic region of $980 \mathrm{~kb}$ formed by 33 exons, is associated with both USH1 and non-syndromic HL, similar to CDH23 [57-59]. Despite its large genome sequence, the intronic sequence can be up to $150 \mathrm{~kb}$, which results in the longest isoform of 1955 amino acids. PCDH15 belongs to the cadherin superfamily 
and encodes the protocadherin protein, which, by alternative splicing, results in several isoforms with different functions $[57,60]$. In both inner ear and photoreceptors, protocadherin 15 shares almost all of its functions with cadherin 23. It has been suggested that it is implicated in the elasticity in mechanotransduction in the tip links in addition to the conservation of calyceal pathways of photoreceptors [55,61-65].

\subsection{USH1G}

USH1G is the smallest USH gene, having a $7 \mathrm{~kb}$ genomic region and containing three exons, two of which are coding. It has been associated with USH1 and atypical USH, but, in recent years, it has also been described as possibly being responsible for non-syndromic HL [66-68]. SANS is a protein of 461 amino acids encoded by USH1G and, as a scaffold protein, it contains SAM domains and ankyrin repeats. This protein takes part in tip link maintenance and acts as a vehicle for molecules across the microtubules [69-74].

\subsection{CIB2}

The CIB2 gene comprises only six exons and it was last of the USH-labelled genes because of the findings of a consanguineous family. Several years later, this gene was also associated with non-syndromic HL [75-78]. Contrary to HL, the implication of CIB2 in USH cases has been questioned, including in the study of Riazuddin et al., suggesting that the USH family with CIB2 mutations may be a disease phenocopy. However, the implication of CIB2 in the inner ear and retina seems to be correct [79]. As its name indicates, CIB2 codifies the calcium and integrin binding protein 2, which consists of $\mathrm{EF}$ hand $\mathrm{Ca}^{2+}$-binding domains.

\subsection{USH2A}

$\mathrm{USH} 2 \mathrm{~A}$ is the most common mutated gene among USH cases and was the first gene described as being responsible for USH2 [80,81], which is highly related to the prevalence of the c.2299delG change [82,83]. Moreover, USH2A is also implicated in non-syndromic RP cases $[84,85]$. As one of the largest USH genes, it encompasses a genomic sequence of $800 \mathrm{~kb}$ and a coding region of 72 exons. The first 21 exons give rise to the extracellular isoform a with 1546 amino acids $[86,87]$. The longer isoform (isoform $b$ ) includes additional 51 exons and produces a transmembrane protein with a length of 5202 amino acids [88]. In addition, an alternative splicing of exon 71 results in an isoform whose expression is specific to the inner ear [89]. In the inner ear, isoform $b$ cooperates with the ADGRV1 protein to join the stereocilia near its emergent region [89-91]. In the retina, its localization in the enveloping region between the connecting cilium and the inner segment of photoreceptors is related to the transport of the molecules to the outer segment and the preservation of these cells in time [92]. Contrarily, isoform a is limited to basement membranes in both stereocilia and photoreceptors [93].

\section{8. $A D G R V 1$}

The ADGRV1 gene, previously known as VLGR1 and GPR98, is the second most prevalent gene in USH2 cases and was first described in 2004 [94]. This gene is considered to have the largest coding sequence among the USH genes [95,96]. ADGRV1 encodes the adhesion G-protein coupled receptor V1, whose largest isoform includes 90 exons (6306 amino acids), although it codifies two more isoforms. Growth and organization of stereocilia is carried out by this protein in cooperation with usherin. Adhesion G-protein coupled receptor V1 cooperates in nearly all of the functions of usherin due to their same localization $[71,90,97]$.

\subsection{WHRN}

The WHRN gene is responsible for USH2 cases [98]. Its coding sequence is alternatively spliced, producing several isoforms, among which two, known both as whirlin, are the most significant [27]. The 12 exons included in the coding sequence of WHRN are translated 
into the longest isoform, which has a length of 907 amino acids, whereas the shortest begins in the sixth exon, and thus lacks two PDZ domains of the $N$-terminal region [99]. It has been observed that mutations affecting the common PDZ domain in both isoforms produce non-syndromic HL, whereas those localized to the remaining protein domains cause USH2 [100-105]. This is supported by findings in mice that displayed alterations in the auditory system when the short isoform was altered, and because of the unique expression of the longest isoform in the retina, which demonstrates that mutations in the two final PDZ domains cause USH2 [106,107]. Whirlin is involved in diverse functions not only in the inner ear and photoreceptors, but also in brain development [106]. Whirlin anchors usherin and ADGRV1 proteins by their cytoplasmic regions in the inner ear; the shortest whirlin mediates the regulation of stereocilia growth via its expression in the tip links, and the largest manages the hair bundle organization [108-111]. In addition, in the retina, whirlin expresses in the connecting cilium and also localizes to the synaptic region [112].

\subsection{CLRN1}

CLRN1 is the only gene known to be causative of USH3 and has also been described as being responsible for nonsyndromic RP. Even though mutations in CLRN1 are rare, the prevalence of this USH subtype reaches around $40 \%$ in the Finnish population $[113,114]$. Its sequence of approximately $18 \mathrm{~kb}$ contains four exons and codes for clarin1, a protein with four transmembrane domains [115]. The 11 different splice variants described could explain the wide clinical spectrum reported in USH3 patients [116]. Among the different speculations about its function, it has been concluded that clarin1 expresses in the synapse areas in both cochlea and photoreceptors [117-119].

\subsection{Other Related Genes}

Other genes have been related to USH, but their association with the disease remains unclear due to some contradictions between the symptoms and the few existing reports. A homozygous variant in $A B H D 12$, a gene more commonly associated with PHARC syndrome and RP, was identified in one family that was clinically diagnosed with USH3 [120]. However, these patients underwent clinical examination after the genetic findings, in which one of the two affected members was additionally diagnosed with ataxia. This was consistent with a variant of PHARC and led the authors to propose the neurological syndrome should be taken into account as a differential diagnosis for USH3 cases. The HARS gene was also proposed to be causative of USH3 based on three patients from two different Amish communities carrying the same missense mutation [121]. Nevertheless, no further USH cases due to mutations in HARS have been reported, and other studies have related the gene to other neuropathies [122-125]. It is thus unclear whether HARS is actually an USH gene or involved in a wider phenotypic spectrum. CEP250 was first associated with atypical USH, supported by a phenotype characterized by early onset HL and relatively mild RP [126]; however, two later studies with findings related to the same gene revealed that the ophthalmological features of the respective patients corresponded to a cone-rod dystrophy rather than RP $[20,127]$. The affected members of the index family presented by Khateb and colleagues were also carriers of a PCARE pathogenic mutation, which could have masked the actual pure CEP250 phenotype or had an epistatic effect. Consequently, CEP250 is now categorized as an USH-like gene. Recently, three studies with comparable cases identified ARSG mutations in atypical USH patients, designated as USH type 4 [128-130]. This appears to be a robust new candidate gene responsible for the disease, and ARSG should be included in upcoming genetic screenings. Even though CEP78 was labelled as being causative of atypical USH in a study by Fu and colleagues, the clinical features of the supporting cases of this research and of two previous studies were consistent with cone-rod dystrophy and SNHL [131-133]. Thus, similar to the case of CEP250, CEP78 is another gene responsible for an USH-like phenotype rather than actual USH. Finally, ESPN has been associated with different forms of HL and with one 
case matching USH1 [134]. Furthermore, an interaction of ESPN with WHRN has been reported [135]. Thus, it remains to be seen if this gene will also have a wider disease spectrum and be attributable to USH. In addition to these genes, it should also be noted that PDZD7, further to its association with HL, was proposed as an USH2A modifier and, with $A D G R V 1$, a possible participant in digenic inheritance [136].

\section{The USH Interactome}

USH proteins interact directly with at least one other, thus building a protein network called the "USH interactome" (Figure 1) [137]. This protein complex can be explained because the alteration of any of the proteins results in the manifestation of almost the same clinical signs. It has been reported in several studies that this protein network is mainly present in the stereocilia of hair cells and the periciliary region of photoreceptors. In 2014, it was reported that the interactome was also associated with other proteins related to ciliopathies and retinopathies [73]. The USH interactome core is formed by whirlin, harmonin, and SANS. In the inner ear, the extracellular unions produced by cadherin 23 and protocadherin 15 are linked in this scaffolding core by the tethering with the cytoskeleton or other proteins, such as myosin VIIA. In addition, the interactome is also located in the synaptic region and the periciliary membrane of photoreceptors [1,73].

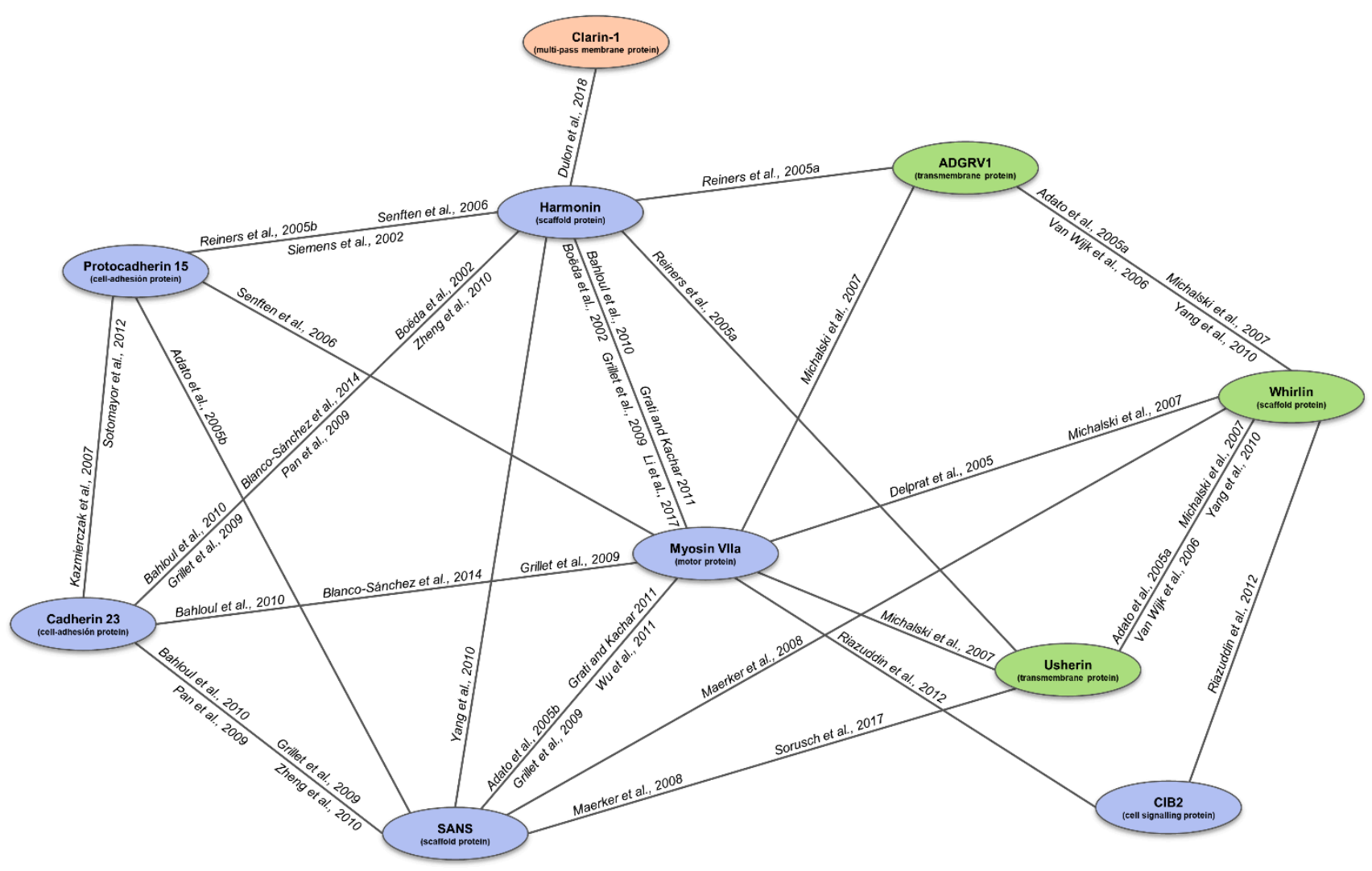

Figure 1. Representation of the USH interactome and supporting literature. The connecting lines represent the detected interactions between the USH1 (blue), USH2 (green) and USH3 (orange) proteins, according to the in vitro and in vivo studies to date (specified next to the lines). Adapted figure from Fuster García (2020). References figure: [10,92,106-108,138-142] [25,26,28,29,143-145] [61,146-148].

\section{Is USH Actually a Ciliopathy?}

The cells affected by USH are the photoreceptors in the retina, and the hair cells of the cochlea and vestibular system, each of which presents ciliary-like structures, namely, the stereocilia and the connecting cilium, respectively. Regarding the inner ear, technically only the vestibular sensory cells present a genuine microtubule-based cilium at the vertex of the 
V-shaped hair bundle, which is the kinocilium; this bundle is only present during development in the cochlear hair cells, before subsequently disappearing $[149,150]$. Nonetheless, this cilium is present during certain stages, and the stereocilia-microvilli resemble ciliary formations. Consequently, many specialists consider USH to be a ciliopathy, which is defined as a group of pathologies that arise from defects in genes that participate in the structure or signaling of cilia [73]. Nonetheless, the use of the term ciliopathy to define USH is controversial. Even though some authors do not include USH in this category [151-153], others incorporate USH into the retinal ciliopathies group [154-156]. Even though the USH proteins are not ciliary proteins, such as those encoded by the genes RPGR, RPGRIP1 or CEP290, or the Bardet Biedl Syndrome genes (BBS family genes), they are clearly essential for the function of photoreceptor cilia and USH should at least be considered a second-order ciliopathy [152].

Numerous tissues have cilia; thus, any genetic variation that alters ciliary functions could affect different organs. Several additional signs have been described in USH patients related to cilia function: bronchiectasis [157], olfactory loss [158,159], subclinical nasal ciliary beat frequency [160], nociception [161], reduced sperm motility [162] and somatosensory deficit [163-165]. However, further evidence is still necessary to consider these characteristics as being USH-related comorbidities.

\section{Animal Models}

Animal models have contributed significantly to elucidate the molecular mechanisms of Usher syndrome and have been widely used in the development of therapeutic strategies to preserve both vision and hearing (Table 2) [166].

The first USH animal models manifested features and conducts corresponding to a hearing loss phenotype, such as deafness, circling behavior and head-tossing movements. Due to the high conservation between the genetic pathways that regulate auditory perception in mice and humans, all current available USH mutant mice well mimic the impairment of human hearing. Each of these reproduces the characteristic early-onset hearing loss and vestibular defects as found in USH1 patients; however, none of these mouse models shows retinal degeneration, with the exception of the Ush1c knock-in mouse, generated to study the c.216G >A mutation, which displays hearing loss, vestibular defects and retinal degeneration [167]. A spontaneous mutant USH2 mouse model (kunming) showed early-onset retinal degeneration, but harbored mutations in two genes implicated in inherited retinal dystrophies: Ush2a and Pde6b [168]. In addition, a Ush2a knock-out mouse presented only mild late-onset retinal degeneration [93]. The third model is a murine model that has a disruption of the $\mathrm{N}$-terminal PDZ domains of whirlin, which recapitulates the human USH2 phenotype [106].

In general, USH mouse models poorly recapitulate the visual deficiencies manifested in human patients when the orthologous genes are disrupted. This could be due to the fact that, in mouse photoreceptors, the calyceal processes and periciliary membranes are absent or underdeveloped compared to human photoreceptors $[54,169]$. However, these structures are present and well developed in frogs, fishes, chicks and primates [170].

The second most commonly used animal as a model of USH is the zebrafish. Even though the evolutionary distance of zebrafish from human may pose problems for the study of the disease, most developed models showed early-onset retinal degeneration, which, as previously mentioned, is lacking in most mouse models [171]. The zebrafish ush2a knock-out also recapitulated the auditory abnormalities and later onset of retinal degeneration characteristic of USH2 patients [172].

Despite the numerous USH models described to date, new animal and cellular models are necessary to increase our understanding of the cellular and molecular processes implicated in vision and hearing, and to enable better diagnosis and treatment of patients with USH. 
Table 2. Described animal models of Usher syndrome.

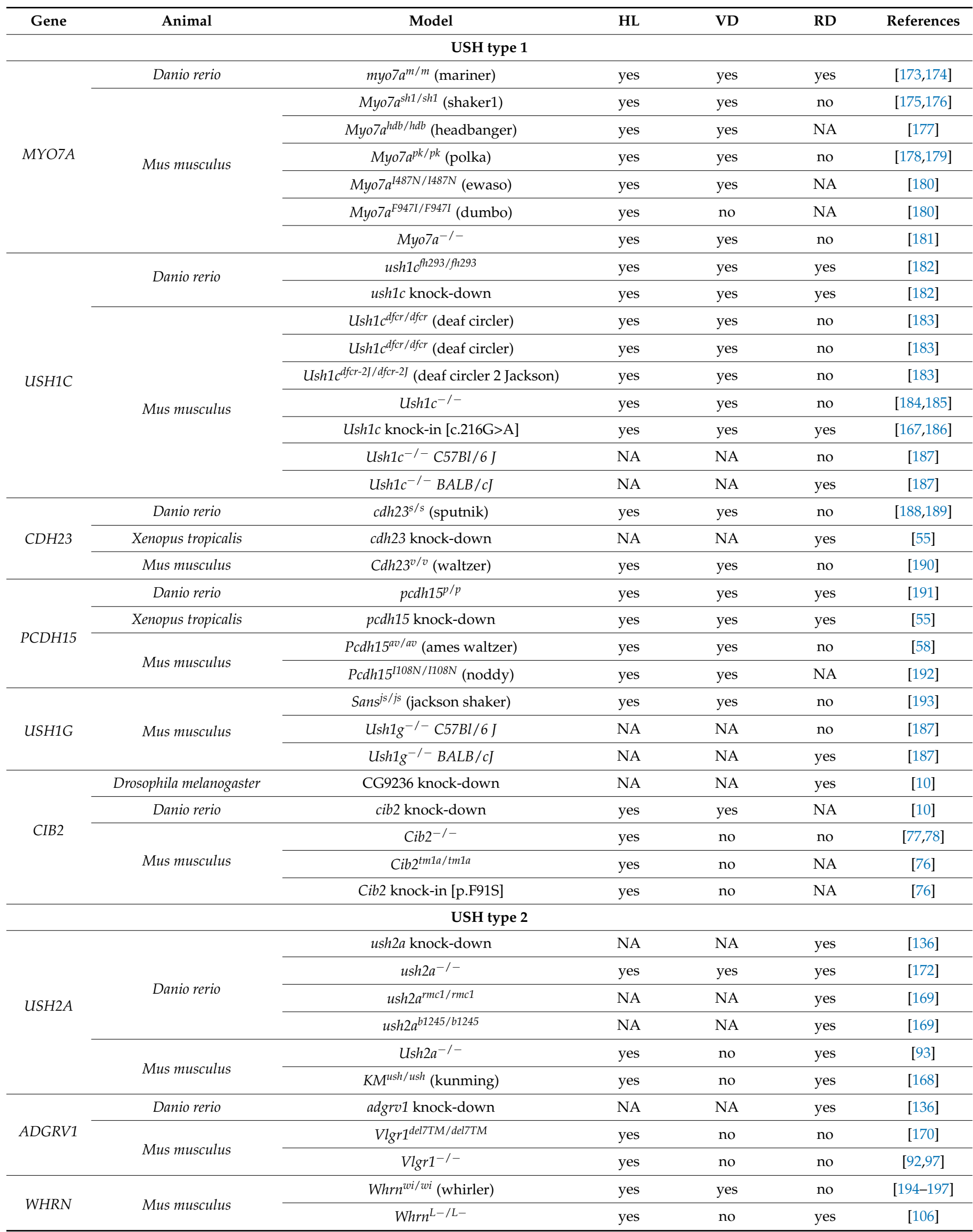


Table 2. Cont.

\begin{tabular}{|c|c|c|c|c|c|c|}
\hline Gene & Animal & Model & HL & VD & RD & References \\
\hline \multicolumn{7}{|c|}{ USH type 3} \\
\hline \multirow{8}{*}{ CLRN1 } & \multirow{2}{*}{ Danio rerio } & clrn1 knock-down & yes & yes & NA & [117] \\
\hline & & $\operatorname{clrn} 1^{-/-}$ & yes & yes & NA & [198] \\
\hline & \multirow{6}{*}{ Mus musculus } & $\mathrm{Clrn} 1^{-/-}$ & yes & yes & no & {$[118,199]$} \\
\hline & & $C l r n 1^{N 48 K / N 48 K}$ & yes & no & NA & [200] \\
\hline & & $C l r n 1^{e x 4-1-}$ & yes & NA & NA & [142] \\
\hline & & Clrn1 extfl $/ f l \mathrm{Myo15} \mathrm{Cr} \mathrm{C}^{+/-}$ & yes & NA & NA & [142] \\
\hline & & Clrn1 ${ }^{-/-}[\mathrm{KO}-\mathrm{TgAC} 1]$ & yes & NA & NA & [201] \\
\hline & & Clrn1 knock-in [N-HA] & no & NA & no & [202] \\
\hline
\end{tabular}

Abbreviations: HL, hearing loss; VD, vestibular dysfunction; RD, retinal degeneration; NA, not available.

\section{Mutational Spectra in the USH Genes: Types, Distribution and Genotype-Phenotype Correlations}

Given the increase in new molecular findings relating to USH, one aim of this study is to review the current gene associations with the disease and to provide an updated genotype-phenotype correlation, including the functional implication of the known pathogenic variants at the transcriptomic and proteomic levels, to better understand the syndromic spectrum and to improve the disease diagnosis. For this analysis, we focus only on the MYO7A, CDH23, ADGRV1, USH1C, USH2A and PCDH15 genes, excluding the remaining four due to their limited number of mutations, which prevents a robust statistical evaluation.

Our study is based on a specific Usher Syndrome database (https:/ / grenada.lumc. nl/LOVD2/Usher_montpellier/USHbases.html, accessed on 6 July 2020; version of July 2020), which collects both genotypic and phenotypic up-to-date information about the USH genes; results are shown in Figures 2-4.

\subsection{Type of Mutations}

It is well known that the USH genes have a significant mutational heterogeneity because pathogenic variants of different natures have been identified, in which the pertinent protein is altered by different molecular pathways. Moreover, in recent years, five deep-intronic variants in USH2A and one in CLRN1 have been identified and functional analyses have demonstrated their implication in the splicing process by the inclusion of a pseudoexon (PE) in the mRNA, leading to a truncating effect [46,203-205]. More deepintronic mutations are expected to be found in the future, further adding to the genetic heterogeneity.

The heterogeneous distribution of every type of mutation described to date in each gene is depicted in Figure 2, which provides an overall representation of nonsense, frameshift, and splicing variants. Furthermore, the large size of the intronic regions in some genes related to a high number of repetitive regions, such as PCDH15 and USH2A, has led to more cases of large rearrangements compared to the other genes [206-209]. As a result, CNVs should be heeded in the capture designs and analyses by HTS or by implementing the method with supplementary techniques, such as Multiplex Ligation-dependent Probe Amplification or Comparative Genomic Hybridization arrays. 

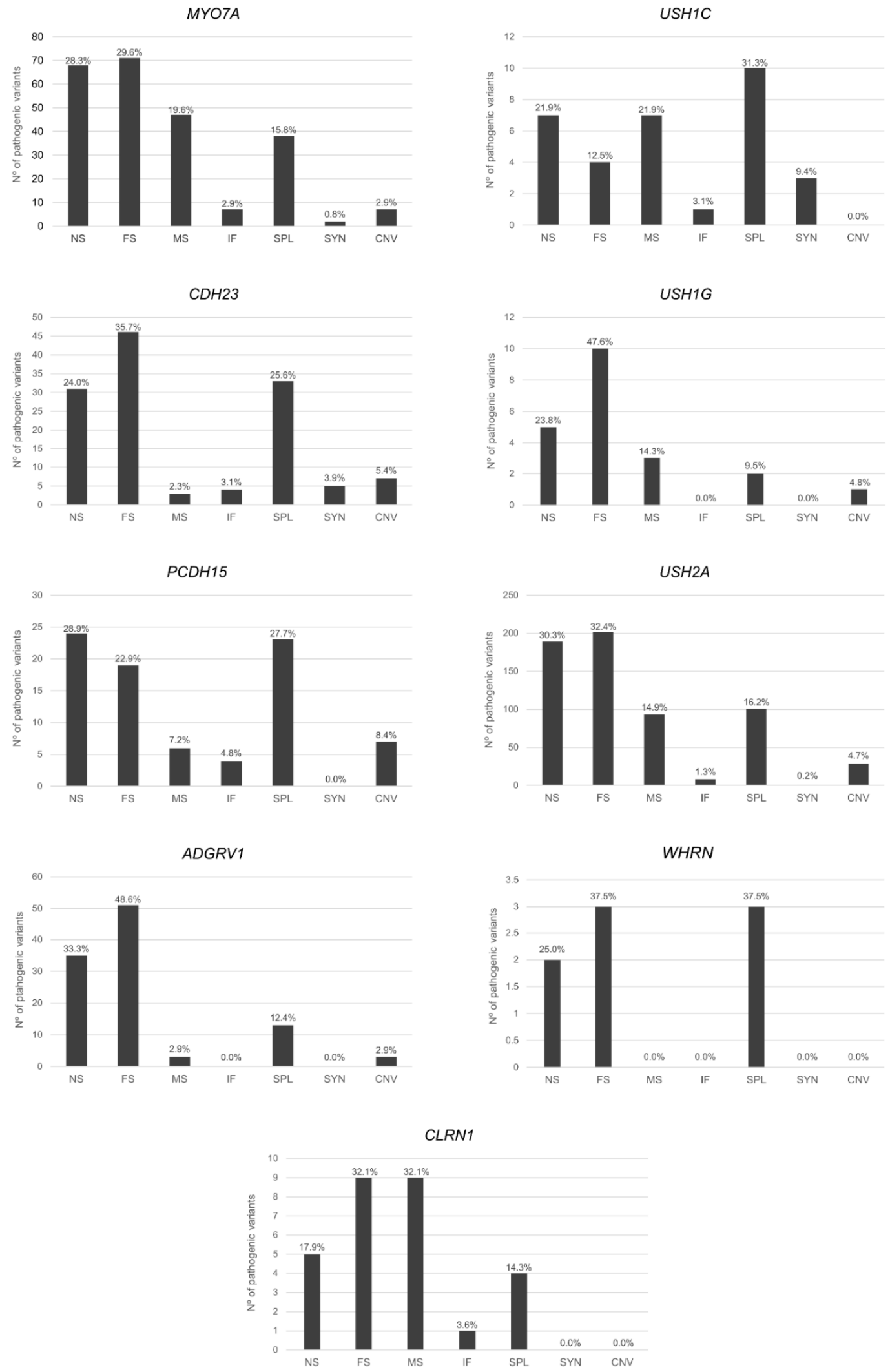

Figure 2. Mutation count in USH genes (MYO7A, USH1C, CDH23, PCDH15, USH2A, ADGRV1). Abbreviations: NS, nonsense variant; $\mathrm{FS}$, frameshift variant; $\mathrm{MS}$, missense variant; IF, in-frame indel variant; SYN, synonymous; SPL, splicing variant. 

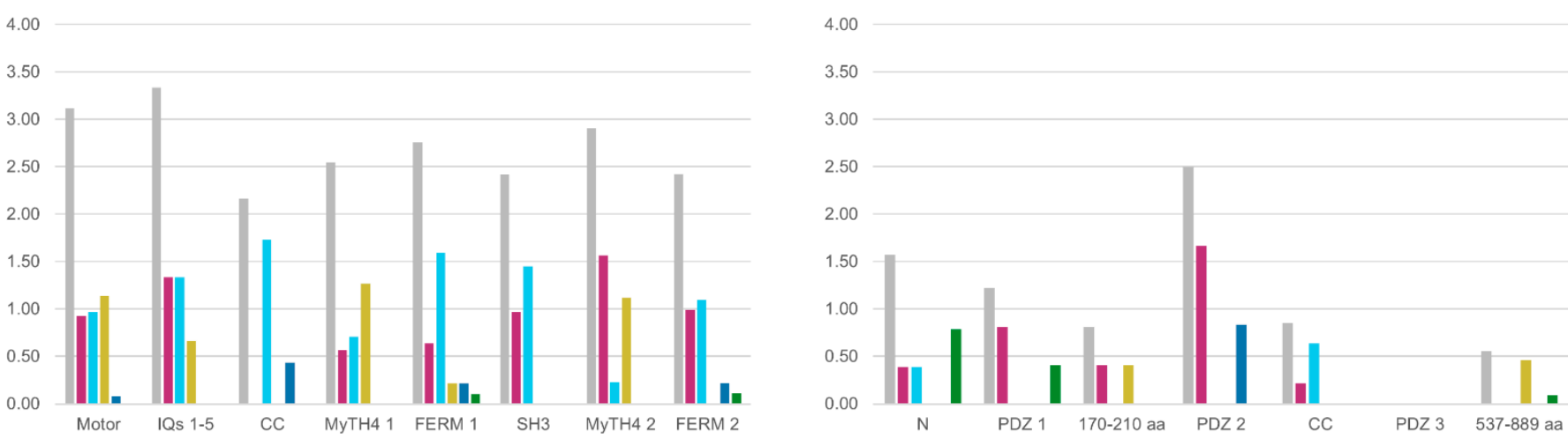

$\mathrm{CDH} 23$
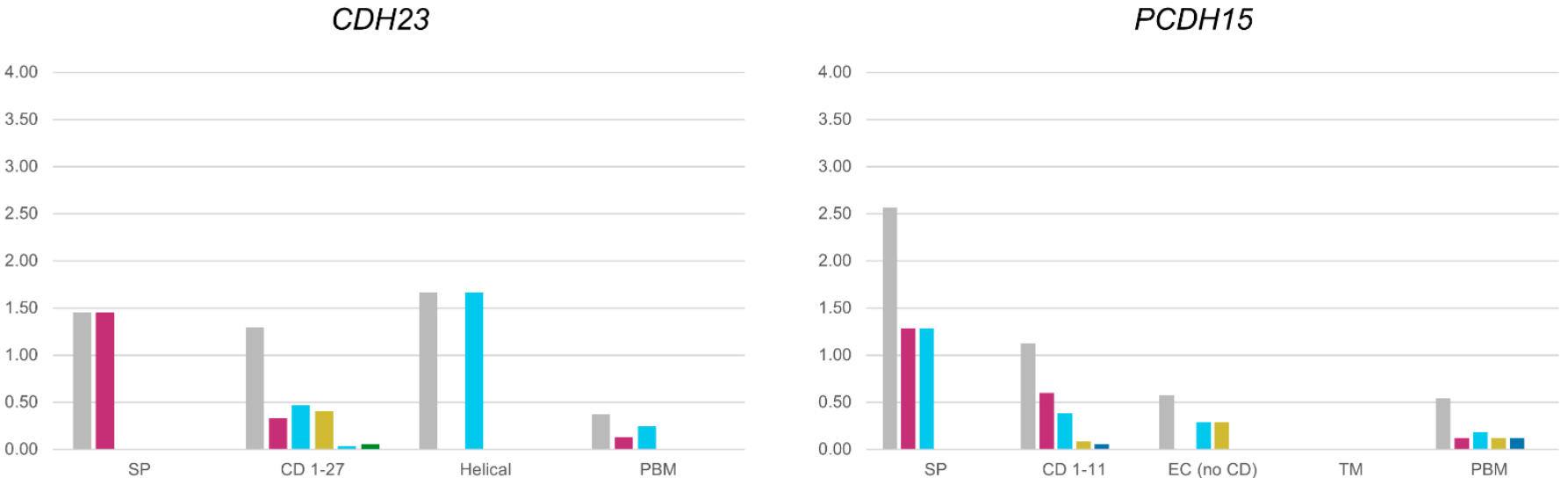

USH2A

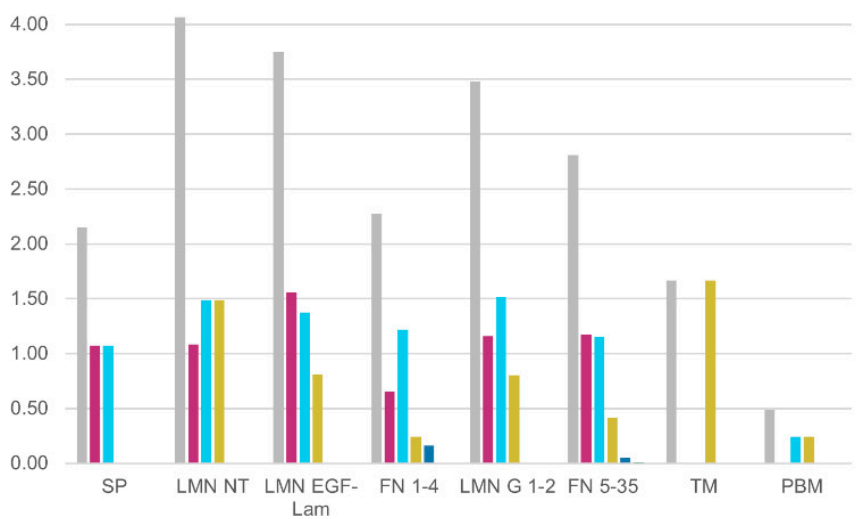

ADGRV1

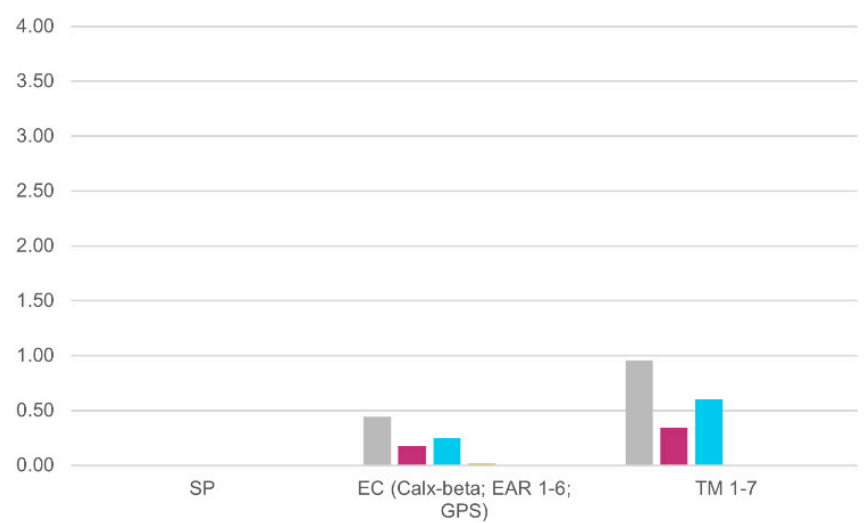

-Total $\square$ Nonsense $\square$ Frameshift Missense $\square$ In-frame $\square$ Synonymous

Figure 3. Mutational ratio in USH protein domains. Mutational ratio for the protein domains for the genes MYO7A, USH1C, $C D H 23, P C D H 15, U S H 2 A$ and ADGRV1, shown on the y-axis. Ratios are calculated counting the number of pathogenic variants of each type located in each domain and normalized with respect to the size of the specific domain. Abbreviations: Motor, motor domain; IQ, IQ calmodulin-binding motif; CC, coil-coiled domain; MyTH4; Myosin Tail Homology 4 domain; FERM, FERM domain (F for 4.1 protein, E for ezrin, R for radixin and M for moesin); SH3; Src Homology 3 domain; N, $N$-terminal domain; PDZ, PDZ domain; aa, amino acids; SP, signal peptide; PBM, PDZ binding domain; CD, cadherin domains; EC, extracellular domain; TM, transmembrane; LMN NT, laminin N-terminal domain; LMN EGF-Lam, laminin EGF-like domain; LMN G; laminin G domain; FN, fibronectin domain. 

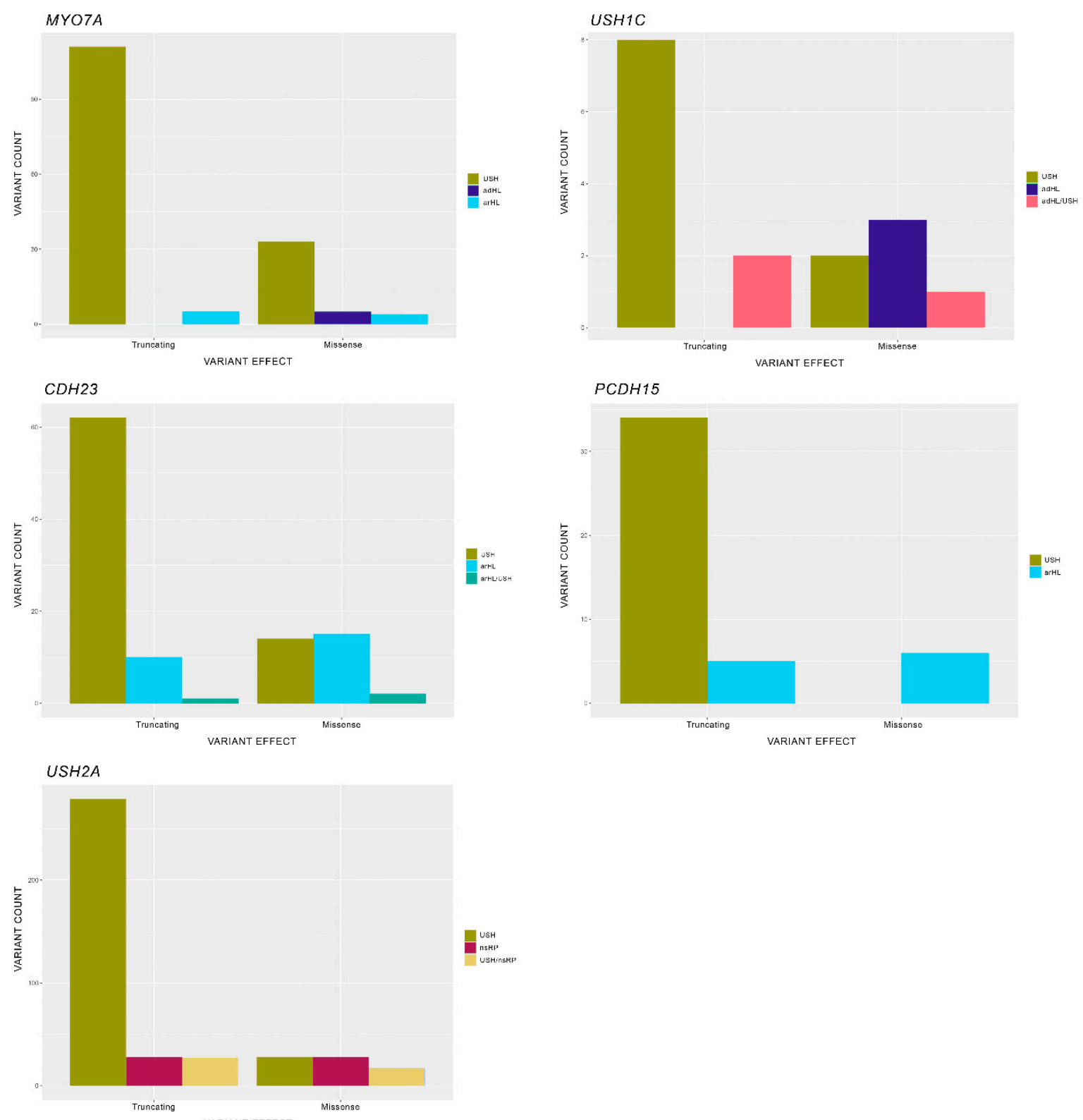

Figure 4. Mutational spectrum per gene for each phenotype. Abbreviations: USH, Usher syndrome; arHL, autosomal recessive hearing loss; adHL, autosomal dominant hearing loss; nsRP, non-syndromic retinitis pigmentosa. ADGRV1 is not included in the representation because all mutations obtained from the database were responsible for only USH and not for additional phenotypes.

\subsection{Mutation Distribution among the USH Proteins Domains}

In addition to the mutation heterogeneity itself, the distribution of mutations throughout the protein sequence and, therefore, the effect on a specific domain, should also be taken into account to explain the functional impact of each type of mutation.

We were interested in studying the possible associations between two categorical variables: domain vs. type of mutation. For each gene, we counted the number of pathogenic variants of each type located in each domain. To take into account the size of the domains, the number of mutations of each type was normalized to the size of the specific domain. To simplify the analysis and data representation, consecutive domains belonging to the same typology were grouped. A Pearson's chi-squared goodness-of-fit test (based on the chi-squared statistical test) was performed with the aim of calculating the 
difference among expected and observed values for each type of mutation in the different gene domains. The aim of a goodness-of-fit test is to estimate whether the theoretical or expected distribution is a good representation of the real data distribution; that is, to assess if the observed data are consistent with either a theoretical or an expected distribution.

\subsubsection{USH2A}

The results revealed significant differences for missense variants whose proportion is higher in the laminin $N$-terminal and the laminin G-like domains ( $p$-value: 0.001147$)$ (Figure 3). In an allelic study of USH2A carried out by Lenassi et al., the missense variants present in their cohort were mostly located in laminin G-like domains, as shown in this review, and in fibronectin type III domains. In our analysis, fibronectin type III domains presented a significantly lower proportion of missense mutations, which may have been a consequence of grouping all fibronectin type III domains to more easily represent the data (Figure 3).

In contrast, some domains accumulate a significantly smaller number of missense variants than expected. The signal peptide only accumulates nonsense and frameshift mutations (Figure 3), suggesting that the significant difference observed for missense frequency ( $p$-value: 0.001147$)$ may be related to the possible tolerance for this type of variant in this domain.

Notably, in USH2A the different localization of a certain type of mutation determines not only its pathogenicity, but also the clinical phenotype depending on the photoreceptor function that is altered. Yu and colleagues, in 2020, proposed two possibilities by which some mutations are associated with RP and USH; the first is related to the two usherin isoforms, and the second to the $\mathrm{C}$ - and $\mathrm{N}$-terminal interactions in the retina and inner ear [210]. Nevertheless, more studies are required to understand the underlying reason why different pathologies can be caused not only by mutations with the same localization, but also by the same missense variant.

\subsubsection{PCDH15}

No significant difference existed among each type of mutation distribution and each protein domain in PCDH15. However, we found a high proportion of nonsense variants in $\mathrm{CD}$ domains, and a low frequency of nonsense variants in extracellular and cytoplasmic domains, which was close to being significantly different from expectations ( $p$-value: 0.0516 ) (Figure 3).

\subsubsection{MYO7A}

In MYO7A, as observed in USH2A, significant differences exist for missense variants, with a higher proportion in the motor domain and the MyTH4-1 and MyTH4-2 domains ( $p$-value: 0.002281 ) (Figure 3).

In contrast, it must be noted that in the $\mathrm{SH} 3$ domain only truncating mutations have been described and the frequency of missense variants is significantly lower than the expected number ( $p$-value: 0.002281 ) (Figure 3). The number of missense variants was also lower than expected for Coiled Coil and FERM domains.

\subsubsection{ADGRV1}

In cytoplasmatic domains 2-4 (included in the transmembrane region in Figure 3), the observed frequency of nonsense variants was higher than expected ( $p$-value: 0.002952 ). In the McMillan et al. study conducted in 2004 [211], the generated mouse model that encoded only the ectodomains of the ADGRV1 gene manifested audiogenic seizures in a manner that clarified the implication of cytoplasmic and transmembrane domains in the auditory function [212]. 


\subsubsection{USH1C}

The statistical analysis showed significant differences in the number of nonsense variants: the frequency was higher than expected in the PDZ1 and PDZ2 domains ( $p$-value: 0.015) (Figure 3). Protein interactions occur through unions among the PDZ domains, which are essential to protein complex arrangements [42], meaning that null variants located in these regions truncate the protein and, therefore, these interactions.

\subsection{6. $\mathrm{CDH} 23$}

Any type of mutation showed significant differences with respect to their localization in the different domains. Notably, in the signal peptide and the helical region of $\mathrm{CDH} 23$, only truncating mutations have been identified (Figure 3). However, only one mutation for each region has been described to date, and we could not identify any significant differences.

\subsection{Types of Mutations and Their Influence in the Phenotype}

Notably, establishing correlations in recessive pathologies between genotype and phenotype is complicated when a major proportion of the study group comprises compound heterozygotes. This is particularly the case if most alleles are private to each family, as in USH.

To investigate whether there is an association between the type of mutation depending on their protein effect and the phenotype, a Pearson's chi-squared test was applied using these two categorical variables. Due to the low number of some types of variants, different variants were grouped into two categories depending on the effect at the protein level: missense and truncating. A second analysis was carried out by combining the type of mutation with the domain in which it was located, to compare it with the phenotype it resulted in; however, we did not obtain any significant results.

\subsubsection{USH2A}

Pearson's chi-squared test showed a relationship between both considered variables for the USH2A gene $\left(p\right.$-value $=1.604 \times 10^{-15}$. There was a higher observed frequency of missense mutations in the nsRP phenotype than expected and a lower missense variant percentage in the USH phenotype than expected; both of these differences were significant. Moreover, the frequency of truncating variants in the nsRP phenotype was significantly fewer than expected (Figures 4 and S1). These findings are in agreement with those observed in other studies for USH2A.

In 2015, Lenassi et al. established an allele hierarchy of USH2A variants in 457 patients from three different cohorts [15], to identify the mutations that resulted in either RP or USH. Their results showed that, although null alleles were responsible for the syndromic form, missense variants were associated with RP in a higher proportion compared to USH, and the phenotype depended on the second causal variant. As mentioned previously, our results also indicate a high prevalence of truncating variants in USH cases in contrast to the higher number of missense variants in RP cases (Figure 4).

Similarly, a cohort of 57 patients carrying p.Cys759Phe (p.C759F) was studied using HTS by Pérez-Carro et al. with the purpose of clarifying the role of this variant as either a RP-causing variant or a possible phenotype modifier [212]. In this study, patients were classified into three categories: the first included patients homozygous for the p.C759F variant; the second contained compound heterozygous patients for p.C759F with another missense variant; and the third compiled compound heterozygous patients for $\mathrm{p} . \mathrm{C} 759 \mathrm{~F}$ with a truncating mutation. Their findings showed that carrying a truncating variant was sufficient to develop an USH phenotype, whereas the other two categories of combinations resulted in the milder form of non-syndromic RP or RP with a late onset hypoacusis. 


\subsubsection{PCDH15}

In $P C D H 15$, the analysis showed significant differences between the considered categories $\left(p\right.$-value $=2.604 \times 10^{-5}$. The observed frequency of missense variants was higher than expected in the DFNB phenotype and lower in the USH phenotype (Figures 4 and S1).

Previous studies have also described an association between missense mutations and non-syndromic deafness in PCDH15 [60,213].

\subsubsection{MYO7A}

The analysis showed a significant higher proportion of missense variant for the DFNA phenotype than expected ( $p$-value: 0.0002928) (Figures 4 and S1). A similar association between missense and HL has been previously reported $[5,49,214]$.

In contrast, a recent study of 53 patients with biallelic MYO7A mutations did not find any statistically significant difference between phenotypic features and the type of mutation [215].

\subsection{4. $\mathrm{CDH} 23$}

As in the case of $M Y O 7 A$, statistical analysis showed significant differences, and indicated a higher frequency of missense variant for the DFNB phenotype in $C D H 23$ than expected ( $p$-value: 0.0001546) (Figures 4 and S1).

In a similar study aiming to determine the phenotype-genotype correlation and a mutation-dependent prognosis for $\mathrm{CDH} 23$, Schultz and colleagues found that heterozygous genotypes consisting of an autosomal recessive HL allele in trans with an USH allele preserved visual and vestibular functions; hence, for this gene it appears that alleles associated with $\mathrm{HL}$ are phenotypically dominant over those causatives of the syndromic form. Even though all of the HL alleles were missense variants (except one amino acid in-frame deletion), USH alleles were of any type, but dominated by those alleles that led to a truncated protein [52].

\subsubsection{USH1C}

Pearson's chi-squared test determined that there was an association between the type of mutations and the different phenotypes ( $p$-value: 0.04224). However, Pearson's residual analysis could not determine more specific associations (Figures 4 and S1).

\section{Conclusions}

As expected, mutation heterogeneity remains a challenge to understanding how the protein and mutation nature correlate with the phenotype, particularly when the complete genotype is not accessible. Establishing a genotype-phenotype correlation is a challenging task for inherited retinal dystrophies. The high number of genes involved, and the large size of some of these genes, have hampered the mutational screening of large cohorts of patients, thus hindering the determination of these statistical relationships. The advent of HTS has allowed massive screenings that, together with a well-curated database such as LOVD, circumvents this problem.

In addition, the rapidly evolving field of gene therapy highlights the importance of an exhaustive molecular diagnosis, because these diagnoses can be directed toward a specific gene or are even mutation dependent. The most promising strategies as potential treatments for USH include approaches based on gene augmentation, antisense oligonucleotides (AONs) and gene editing using the CRISPR/Cas system [166]. Several clinical trials are currently underway using some of these strategies, for USH and other retinal diseases. Among these, a form of gene therapy via gene supplementation (LUXTURNA ${ }^{\mathrm{TM}}$ ) has received FDA approval for Leber Congenital Amaurosis with mutations in RPE65 [216]. This therapeutic strategy, although using dual vectors, is also being used in a European clinical trial for the MYO7A gene (UshTher, Horizon, 2020; \#NCT02065011). Additionally, other studies are focused on the use of AONs to treat mutations in several USH 
genes [217-219], including a phase I/II clinical trial of patients with mutations in exon 13 of USH2A (ProQR, Stellar; \#NCT03780257).

These outstanding scientific advances and the development of innovative therapeutic strategies are leading towards precision medicine. It is thus essential to continue investigating the mechanisms underlying the pathology of USH, performing comprehensive genetic diagnoses and establishing genotype-phenotype correlations that will be indispensable to develop and determine the efficacy of future treatments.

Supplementary Materials: The following are available online at https:/ /www.mdpi.com/article/10 .3390/ijms22136723/s1.

Author Contributions: Conceptualization, C.F.-G., B.G.-B., G.G.-G. and J.M.M.; methodology, C.F.-G., B.G.-B. and A.R.-M.; resources, C.F.-G., B.G.-B. and A.R.-M.; writing-original draft preparation C.F.-G., B.G.-B. and A.R.-M.; writing-review and editing, C.F.-G., B.G.-B., A.R.-M., T.J., E.A., G.G.-G. and J.M.M.; supervision, G.G.-G. and J.M.M.; funding acquisition, J.M.M. All authors have read and agreed to the published version of the manuscript.

Funding: This study was funded by the Project PI19/00303, Health Research Institute Carlos III (ISCIII; Spanish Ministry of Health and Innovation) and the Regional Government of the Valencian Community (PROMETEU /2018/135), with partial support from the European Regional Development Fund (ERDF). ARM is a recipient of a Rio Hortega contract (CM18/00199) from the ISCIII, BGB is a recipient of a predoctoral contract (ACIF/2019/252) from the Government of the Valencian Community and GGG has a postdoctoral contract from CIBERER.

Institutional Review Board Statement: Not applicable.

Informed Consent Statement: Not applicable.

Data Availability Statement: Not applicable.

Acknowledgments: We thank Raquel Gavidia from the Statistics Section of the SCSIE (University of Valencia) for her collaboration in the statistical analyses.

Conflicts of Interest: The authors declare that the research was conducted in the absence of any commercial or financial relationships that could be construed as a potential conflict of interest.

\section{References}

1. Millán, J.M.; Aller, E.; Jaijo, T.; Blanco-Kelly, F.; Gimenez-Pardo, A.; Ayuso, C. An Update on the Genetics of Usher Syndrome. J. Ophthalmol. 2011, 2011, 1-8. [CrossRef]

2. Wafa, T.T.; Faridi, R.; King, K.A.; Zalewski, C.; Yousaf, R.; Schultz, J.M.; Morell, R.J.; Muskett, J.; Turriff, A.; Tsilou, E.; et al. Vestibular phenotype-genotype correlation in a cohort of 90 patients with Usher syndrome. Clin. Genet. 2021, 99, $226-235$. [CrossRef] [PubMed]

3. Davenport, S.L.H.; Omenn, G.S. The Heterogeneity of Usher Syndrome. In Proceedings of the 5th International Conference of Birth Defects, Montreal, QC, Canada, 21-27 August 1977.

4. Weil, D.; Küssel, P.; Blanchard, S.; Levy, G.G.; Levi-Acobas, F.; Drira, M.; Ayadi, H.; Petit, C. The autosomal recessive isolated deafness, DFNB2, and the Usher 1B syndrome are allelic defects of the myosin-VIIA gene. Nat. Genet. 1997, 16, 191-193. [CrossRef] [PubMed]

5. $\quad$ Bork, J.M.; Peters, L.; Riazuddin, S.; Bernstein, S.L.; Ahmed, Z.M.; Ness, S.L.; Polomeno, R.; Ramesh, A.; Schloss, M.; Srisailpathy, C.R.S.; et al. Usher Syndrome 1D and Nonsyndromic Autosomal Recessive Deafness DFNB12 Are Caused by Allelic Mutations of the Novel Cadherin-Like Gene CDH23. Am. J. Hum. Genet. 2001, 68, 26-37. [CrossRef] [PubMed]

6. Ahmed, Z.M.; Smith, T.N.; Riazuddin, S.; Makishima, T.; Ghosh, M.; Bokhari, S.; Menon, P.S.; Deshmukh, D.; Griffith, A.J.; Riazuddin, S.; et al. Nonsyndromic recessive deafness DFNB18 and Usher syndrome type IC are allelic mutations of USHIC. Qual. Life Res. 2002, 110, 527-531. [CrossRef] [PubMed]

7. Ahmed, Z.M.; Riazuddin, S.; Ahmad, J.; Bernstein, S.L.; Guo, Y.; Sabar, M.F.; Sieving, P.; Riazuddin, S.; Griffith, A.J.; Friedman, T.B.; et al. PCDH15 is expressed in the neurosensory epithelium of the eye and ear and mutant alleles are responsible for both USH1F and DFNB23. Hum. Mol. Genet. 2003, 12, 3215-3223. [CrossRef]

8. Ouyang, X.; Xia, X.; Verpy, E.; Du, L.; Pandya, A.; Petit, C.; Balkany, T.; Nance, W.E.; Liu, X. Mutations in the alternatively spliced exons of USH1C cause non-syndromic recessive deafness. Qual. Life Res. 2002, 111, 26-30. [CrossRef]

9. Mburu, P.; Mustapha, M.; Varela, A.; Weil, D.; El-Amraoui, A.; Holme, R.H.; Rump, A.; Hardisty, R.E.; Blanchard, S.; Coimbra, R.S.; et al. Defects in whirlin, a PDZ domain molecule involved in stereocilia elongation, cause deafness in the whirler mouse and families with DFNB. Nat. Genet. 2003, 34, 421-428. [CrossRef] 
10. Riazuddin, S.; Belyantseva, I.A.; Giese, A.P.J.; Lee, K.; Indzhykulian, A.A.; Nandamuri, S.P.; Yousaf, R.; Sinha, G.P.; Lee, S.; Terrell, D.; et al. Alterations of the CIB2 calcium- and integrin-binding protein cause Usher syndrome type 1J and nonsyndromic deafness DFNB48. Nat. Genet. 2012, 44, 1265-1271. [CrossRef]

11. Oonk, A.M.M.; van Huet, R.A.C.; Leijendeckers, J.M.; Oostrik, J.; Venselaar, H.; van Wijk, E.; Beynon, A.; Kunst, H.P.M.; Hoyng, C.B.; Kremer, H.; et al. Nonsyndromic Hearing Loss Caused by USH1G Mutations. Ear Hear. 2015, 36, 205-211. [CrossRef]

12. Vona, B.; Lechno, S.; Hofrichter, M.A.H.; Hopf, S.; Läßig, A.K.; Haaf, T.; Keilmann, A.; Zechner, U.; Bartsch, O. Confirmation of PDZD7 as a Nonsyndromic Hearing Loss Gene. Ear Hear. 2016, 37, e238-e246. [CrossRef]

13. Liu, X.-Z.; Walsh, J.; Tamagawa, Y.; Kitamura, K.; Nishizawa, M.; Steel, K.P.; Brown, S.D. Autosomal dominant non-syndromic deafness caused by a mutation in the myosin VIIA gene. Nat. Genet. 1997, 17, 268-269. [CrossRef]

14. Khan, M.I.; Kersten, F.F.; Azam, M.; Collin, R.W.; Hussain, A.; Shah, S.T.-A.; Keunen, J.E.; Kremer, H.; Cremers, F.P.; Qamar, R.; et al. CLRN1 Mutations Cause Nonsyndromic Retinitis Pigmentosa. Ophthalmology 2011, 118, 1444-1448. [CrossRef]

15. Lenassi, E.; Vincent, A.; Li, Z.; Saihan, Z.; Coffey, A.J.; Steele-Stallard, H.B.; Moore, A.T.; Steel, K.P.; Luxon, L.M.; Héon, E.; et al. A detailed clinical and molecular survey of subjects with nonsyndromic USH2A retinopathy reveals an allelic hierarchy of disease-causing variants. Eur. J. Hum. Genet. 2015, 23, 1318-1327. [CrossRef] [PubMed]

16. Bonnet, C.; Grati, M.; Marlin, S.; Levilliers, J.; Hardelin, J.-P.; Parodi, M.; Niasme-Grare, M.; Zelenika, D.; Délépine, M.; Feldmann, D.; et al. Complete exon sequencing of all known Usher syndrome genes greatly improves molecular diagnosis. Orphanet J. Rare Dis. 2011, 6, 21. [CrossRef] [PubMed]

17. Aparisi, M.J.; Aller, E.; Fuster-García, C.; García-García, G.; Rodrigo, R.; Vazquez-Manrique, R.P.; Blanco-Kelly, F.; Ayuso, C.; Roux, A.-F.; Jaijo, T.; et al. Targeted next generation sequencing for molecular diagnosis of Usher syndrome. Orphanet J. Rare Dis. 2014, 9, 168. [CrossRef] [PubMed]

18. Roberts, L.; George, S.; Greenberg, J.; Ramesar, R.S. A Founder Mutation inMYO7AUnderlies a Significant Proportion of Usher Syndrome in Indigenous South Africans: Implications for the African Diaspora. Investig. Opthalmol. Vis. Sci. 2015, 56, 6671-6678. [CrossRef]

19. Zong, L.; Chen, K.; Wu, X.; Liu, M.; Jiang, H. Compound heterozygous MYO7A mutations segregating Usher syndrome type 2 in a Han family. Int. J. Pediatr. Otorhinolaryngol. 2016, 90, 150-155. [CrossRef]

20. Fuster-García, C.; García-García, G.; Jaijo, T.; Fornés, N.; Ayuso, C.; Fernández-Burriel, M.; La Morena, A.S.-D.; Aller, E.; Millán, J.M. High-throughput sequencing for the molecular diagnosis of Usher syndrome reveals 42 novel mutations and consolidates CEP250 as Usher-like disease causative. Sci. Rep. 2018, 8, 17113. [CrossRef] [PubMed]

21. Kimberling, W.; Möller, C.; Davenport, S.; Priluck, I.; Beighton, P.; Greenberg, J.; Reardon, W.; Weston, M.; Kenyon, J.; Grunkemeyer, J.; et al. Linkage of usher syndrome type I gene (USH1B) to the long arm of chromosome 11. Genomics 1992, 14, 988-994. [CrossRef]

22. Well, D.; Blanchard, S.; Kaplan, J.; Guilford, P.; Gibson, F.; Walsh, J.; Mburu, P.; Varela, A.; Levilliers, J.; Weston, M.D.; et al. Defective myosin VIIA gene responsible for Usher syndrome type IB. Nature 1995, 374, 60-61. [CrossRef]

23. Jaijo, T.; Aller, E.; Beneyto, M.; Najera, C.; Graziano, C.; Turchetti, D.; Seri, M.; Ayuso, C.; Baiget, M.; Moreno, F.; et al. MYO7A mutation screening in Usher syndrome type I patients from diverse origins. J. Med. Genet. 2006, 44, e71. [CrossRef]

24. Jouret, G.; Poirsier, C.; Spodenkiewicz, M.; Jaquin, C.; Gouy, E.; Arndt, C.; Labrousse, M.; Gaillard, D.; Doco-Fenzy, M.; Lebre, A.-S. Genetics of Usher Syndrome: New Insights from a Meta-analysis. Otol. Neurotol. 2019, 40, 121-129. [CrossRef]

25. Liu, X.-Z.; Hope, C.; Walsh, J.; Newton, V.; Ke, X.M.; Liang, C.Y.; Xu, L.R.; Zhou, J.M.; Trump, D.; Steel, K.P.; et al. Mutations in the Myosin VIIA Gene Cause a Wide Phenotypic Spectrum, Including Atypical Usher Syndrome. Am. J. Hum. Genet. 1998, 63, 909-912. [CrossRef]

26. Mathur, P.D.; Yang, J. Usher syndrome and non-syndromic deafness: Functions of different whirlin isoforms in the cochlea, vestibular organs, and retina. Hear. Res. 2019, 375, 14-24. [CrossRef] [PubMed]

27. Riazuddin, S.; Nazli, S.; Ahmed, Z.M.; Yang, Y.; Zulfiqar, F.; Shaikh, R.S.; Zafar, A.U.; Khan, S.N.; Sabar, F.; Javid, F.T.; et al. Mutation spectrum ofMYO7Aand evaluation of a novel nonsyndromic deafnessDFNB2allele with residual function. Hum. Mutat. 2008, 29, 502-511. [CrossRef] [PubMed]

28. Kelley, P.M.; Weston, M.D.; Chen, Z.-Y.; Orten, D.J.; Hasson, T.; Overbeck, L.D.; Pinnt, J.; Talmadge, C.B.; Ing, P.; Mooseker, M.S.; et al. The Genomic Structure of the Gene Defective in Usher Syndrome Type Ib (MYO7A). Genome 1997, 40, 73-79. [CrossRef] [PubMed]

29. Inoue, A.; Ikebe, M. Characterization of the Motor Activity of Mammalian Myosin VIIA. J. Biol. Chem. 2003, 278, 5478-5487. [CrossRef] [PubMed]

30. Li, J.; He, Y.; Weck, M.L.; Lu, Q.; Tyska, M.J.; Zhang, M. Structure of Myo7b/USH1C complex suggests a general PDZ domain binding mode by MyTH4-FERM myosins. Proc. Natl. Acad. Sci. USA 2017, 114, E3776-E3785. [CrossRef] [PubMed]

31. Wu, L.; Pan, L.; Wei, Z.; Zhang, M. Structure of MyTH4-FERM Domains in Myosin VIIa Tail Bound to Cargo. Science 2011, 331, 757-760. [CrossRef]

32. Gibbs, D.; Diemer, T.; Khanobdee, K.; Hu, J.; Bok, D.; Williams, D.S. Function of MYO7A in the Human RPE and the Validity of Shaker1 Mice as a Model for Usher Syndrome 1B. Investig. Opthalmol. Vis. Sci. 2010, 51, 1130-1135. [CrossRef]

33. Liu, X.; Udovichenko, I.P.; Brown, S.D.; Steel, K.P.; Williams, D.S. Myosin VIIa Participates in Opsin Transport through the Photoreceptor Cilium. J. Neurosci. 1999, 19, 6267-6274. [CrossRef] [PubMed] 
34. Wolfrum, U.; Schmitt, A. Rhodopsin transport in the membrane of the connecting cilium of mammalian photoreceptor cells. Cell Motil. Cytoskelet. 2000, 46, 95-107. [CrossRef]

35. El-Amraoui, A.; Schonn, J.; Küssel-Andermann, P.; Blanchard, S.; Desnos, C.; Henry, J.; Wolfrum, U.; Darchen, F.; Petit, C. MyRIP, a novel Rab effector, enables myosin VIIa recruitment to retinal melanosomes. EMBO Rep. 2002, 3, 463-470. [CrossRef] [PubMed]

36. Gibbs, D.; Kitamoto, J.; Williams, D.S. Abnormal phagocytosis by retinal pigmented epithelium that lacks myosin VIIa, the Usher syndrome 1B protein. Proc. Natl. Acad. Sci. USA 2003, 100, 6481-6486. [CrossRef]

37. Boëda, B.; El-Amraoui, A.; Bahloul, A.; Goodyear, R.; Daviet, L.; Blanchard, S.; Perfettini, I.; Fath, K.R.; Shorte, S.; Reiners, J.; et al. Myosin VIIa, Harmonin and Cadherin 23, Three Usher I Gene Products That Cooperate to Shape the Sensory Hair Cell Bundle. EMBO J. 2002, 21, 6689-6699. [CrossRef]

38. Grati, M.; Kachar, B. Myosin VIIa and sans localization at stereocilia upper tip-link density implicates these Usher syndrome proteins in mechanotransduction. Proc. Natl. Acad. Sci. USA 2011, 108, 11476-11481. [CrossRef]

39. Kros, C.J.; Marcotti, W.; Van Netten, S.M.; Self, T.J.; Libby, R.T.; Brown, S.D.M.; Richardson, G.P.; Steel, K.P. Reduced climbing and increased slipping adaptation in cochlear hair cells of mice with Myo7a mutations. Nat. Neurosci. 2001, 5, 41-47. [CrossRef]

40. Bitner-Glindzicz, M.; Lindley, K.J.; Rutland, P.; Blaydon, D.; Smith, V.V.; Milla, P.J.; Hussain, K.; Furth-Lavi, J.; Cosgrove, K.E.; Shepherd, R.M.; et al. A recessive contiguous gene deletion causing infantile hyperinsulinism, enteropathy and deafness identifies the Usher type 1C gene. Nat. Genet. 2000, 26, 56-60. [CrossRef]

41. Verpy, E.; Leibovici, M.; Zwaenepoel, I.; Liu, X.-Z.; Gal, A.; Salem, N.; Mansour, A.M.; Blanchard, S.; Kobayashi, I.; Keats, B.J.; et al. A defect in harmonin, a PDZ domain-containing protein expressed in the inner ear sensory hair cells, underlies Usher syndrome type 1C. Nat. Genet. 2000, 26, 51-55. [CrossRef] [PubMed]

42. Jain, P.K.; Lalwani, A.K.; Li, X.C.; Singleton, T.L.; Smith, T.N.; Chen, A.; Deshmukh, D.; Verma, I.C.; Smith, R.J.; Wilcox, E.R. A Gene for Recessive Nonsyndromic Sensorineural Deafness (DFNB18) Maps to the Chromosomal Region 11p14-p15.1 Containing the Usher Syndrome Type 1C Gene. Genomics 1998, 50, 290-292. [CrossRef] [PubMed]

43. Reiners, J.; Van Wijk, E.; Märker, T.; Zimmermann, U.; Jürgens, K.; Brinke, H.T.; Overlack, N.; Roepman, R.; Knipper, M.; Kremer, H.; et al. Scaffold protein harmonin (USH1C) provides molecular links between Usher syndrome type 1 and type. Hum. Mol. Genet. 2005, 14, 3933-3943. [CrossRef] [PubMed]

44. Baux, D.; Vaché, C.; Blanchet, C.; Willems, M.; Baudoin, C.; Moclyn, M.; Faugère, V.; Touraine, R.; Isidor, B.; Dupin-Deguine, D.; et al. Combined genetic approaches yield a $48 \%$ diagnostic rate in a large cohort of French hearing-impaired patients. Sci. Rep. 2017, 7, 16783. [CrossRef]

45. Khateb, S.; Zelinger, L.; Ben-Yosef, T.; Merin, S.; Crystal-Shalit, O.; Gross, M.; Banin, E.; Sharon, D. Exome Sequencing Identifies a Founder Frameshift Mutation in an Alternative Exon of USH1C as the Cause of Autosomal Recessive Retinitis Pigmentosa with Late-Onset Hearing Loss. PLoS ONE 2012, 7, e51566. [CrossRef] [PubMed]

46. Sheng, M.; Sala, C. PDZ Domains and the Organization of Supramolecular Complexes. Annu. Rev. Neurosci. 2001, $24,1-29$. [CrossRef] [PubMed]

47. Reiners, J.; Nagel-Wolfrum, K.; Jürgens, K.; Märker, T.; Wolfrum, U. Molecular basis of human Usher syndrome: Deciphering the meshes of the Usher protein network provides insights into the pathomechanisms of the Usher disease. Exp. Eye Res. 2006, 83, 97-119. [CrossRef] [PubMed]

48. Bolz, H.; Von Brederlow, B.; Ramírez, A.; Bryda, E.C.; Kutsche, K.; Nothwang, H.G.; Seeliger, M.; Cabrera, M.D.C.-S.; Vila, M.C.; Molina, O.P.; et al. Mutation of $\mathrm{CDH} 23$, encoding a new member of the cadherin gene family, causes Usher syndrome type 1D. Nat. Genet. 2001, 27, 108-112. [CrossRef]

49. Astuto, L.M.; Bork, J.M.; Weston, M.D.; Askew, J.W.; Fields, R.R.; Orten, D.J.; Ohliger, S.J.; Riazuddin, S.; Morell, R.; Khan, S.; et al. CDH23 Mutation and Phenotype Heterogeneity: A Profile of 107 Diverse Families with Usher Syndrome and Nonsyndromic Deafness. Am. J. Hum. Genet. 2002, 71, 262-275. [CrossRef]

50. Baux, D.; Faugère, V.; Larrieu, L.; Le Guédard-Méreuze, S.; Hamroun, D.; Béroud, C.; Malcolm, S.; Claustres, M.; Roux, A.-F. UMD-USHbases: A comprehensive set of databases to record and analyse pathogenic mutations and unclassified variants in seven Usher syndrome causing genes. Hum. Mutat. 2008, 29, E76-E87. [CrossRef]

51. Becirovic, E.; Ebermann, I.; Nagy, D.; Zrenner, E.; Seeliger, M.W.; Bolz, H.J. Usher syndrome type 1 due to missense mutations on bothCDH23 alleles: Investigation of mRNA splicing. Hum. Mutat. 2008, 29, 452. [CrossRef]

52. Schultz, J.M.; Bhatti, R.; Madeo, A.C.; Turriff, A.; Muskett, J.A.; Zalewski, C.K.; King, K.A.; Ahmed, Z.M.; Riazuddin, S.; Ahmad, N.; et al. Allelic hierarchy of CDH23 mutations causing non-syndromic deafness DFNB12 or Usher syndrome USH1D in compound heterozygotes. J. Med. Genet. 2011, 48, 767-775. [CrossRef]

53. Jaiganesh, A.; Narui, Y.; Araya-Secchi, R.; Sotomayor, M. Beyond Cell-Cell Adhesion: Sensational Cadherins for Hearing and Balance. Cold Spring Harb. Perspect. Biol. 2017, 10, a029280. [CrossRef]

54. Sahly, I.; Dufour, E.; Schietroma, C.; Michel, V.; Bahloul, A.; Perfettini, I.; Pepermans, E.; Estivalet, A.; Carette, D.; Aghaie, A.; et al. Localization of Usher 1 proteins to the photoreceptor calyceal processes, which are absent from mice. J. Cell Biol. 2012, 199, 381-399. [CrossRef]

55. Schietroma, C.; Parain, K.; Estivalet, A.; Aghaie, A.; De Monvel, J.B.; Picaud, S.; Sahel, J.-A.; Perron, M.; El-Amraoui, A.; Petit, C. Usher syndrome type 1-associated cadherins shape the photoreceptor outer segment. J. Cell Biol. 2017, 216, 1849-1864. [CrossRef]

56. Takahashi, S.; Mui, V.J.; Rosenberg, S.K.; Homma, K.; Cheatham, M.A.; Zheng, J. Cadherin 23-C Regulates Microtubule Networks by Modifying CAMSAP3's Function. Sci. Rep. 2016, 6, 28706. [CrossRef] [PubMed] 
57. Ahmed, Z.M.; Riazuddin, S.; Bernstein, S.L.; Ahmed, Z.; Khan, S.; Griffith, A.J.; Morell, R.; Friedman, T.B.; Riazuddin, S.; Wilcox, E.R. Mutations of the Protocadherin Gene PCDH15 Cause Usher Syndrome Type 1F. Am. J. Hum. Genet. 2001, 69, 25-34. [CrossRef]

58. Ahmed, Z.M.; Goodyear, R.; Riazuddin, S.; Lagziel, A.; Legan, P.K.; Behra, M.; Burgess, S.M.; Lilley, K.S.; Wilcox, E.R.; Griffith, A.J.; et al. The Tip-Link Antigen, a Protein Associated with the Transduction Complex of Sensory Hair Cells, Is Protocadherin-15. J. Neurosci. 2006, 26, 7022-7034. [CrossRef] [PubMed]

59. Ahmed, Z.M.; Riazuddin, S.; Aye, S.; Ali, R.A.; Venselaar, H.; Anwar, S.; Belyantseva, P.P.; Qasim, M.; Riazuddin, S.; Friedman, T.B. Gene structure and mutant alleles of PCDH15: Nonsyndromic deafness DFNB23 and type 1 Usher syndrome. Qual. Life Res. 2008, 124, 215-223. [CrossRef] [PubMed]

60. Alagramam, K.N.; Yuan, H.; Kuehn, M.H.; Murcia, C.L.; Wayne, S.; Srisailpathy, C.S.; Lowry, R.B.; Knaus, R.; Van Laer, L.; Bernier, F.; et al. Mutations in the novel protocadherin PCDH15 cause Usher syndrome type 1F. Hum. Mol. Genet. 2001, 10, 1709-1718. [CrossRef]

61. Kazmierczak, P.; Sakaguchi, H.; Tokita, J.; Wilson-Kubalek, E.M.; Milligan, R.A.; Müller, U.; Kachar, B. Cadherin 23 and protocadherin 15 interact to form tip-link filaments in sensory hair cells. Nat. Cell Biol. 2007, 449, 87-91. [CrossRef]

62. McGrath, J.; Roy, P.; Perrin, B.J. Stereocilia morphogenesis and maintenance through regulation of actin stability. Semin. Cell Dev. Biol. 2017, 65, 88-95. [CrossRef] [PubMed]

63. Araya-Secchi, R.; Neel, B.L.; Sotomayor, M. An elastic element in the protocadherin-15 tip link of the inner ear. Nat. Commun. 2016, 7, 13458. [CrossRef]

64. Bartsch, T.F.; Hengel, F.E.; Oswald, A.; Dionne, G.; Chipendo, I.V.; Mangat, S.S.; El Shatanofy, M.; Shapiro, L.; Müller, U.; Hudspeth, A.J. Elasticity of individual protocadherin 15 molecules implicates tip links as the gating springs for hearing. Proc. Natl. Acad. Sci. USA 2019, 116, 11048-11056. [CrossRef]

65. Powers, R.E.; Gaudet, R.; Sotomayor, M. A Partial Calcium-Free Linker Confers Flexibility to Inner-Ear Protocadherin-15. Structure 2017, 25, 482-495. [CrossRef]

66. Weil, D.; El-Amraoui, A.; Masmoudi, S.; Mustapha, M.; Kikkawa, Y.; Lainé, S.; Delmaghani, S.; Adato, A.; Nadifi, S.; Ben Zina, Z.; et al. Usher syndrome type I G (USH1G) is caused by mutations in the gene encoding SANS, a protein that associates with the USH1C protein, harmonin. Hum. Mol. Genet. 2003, 12, 463-471. [CrossRef]

67. Bashir, R.; Fatima, A.; Naz, S. A frameshift mutation in SANS results in atypical Usher syndrome. Clin. Genet. 2010, 78, 601-603. [CrossRef] [PubMed]

68. Kalay, E.; De Brouwer, A.P.M.; Caylan, R.; Nabuurs, S.B.; Wollnik, B.; Karaguzel, A.; Heister, J.G.A.M.; Erdol, H.; Cremers, F.P.M.; Cremers, C.W.R.J.; et al. A novel D458V mutation in the SANS PDZ binding motif causes atypical Usher syndrome. J. Mol. Med. 2005, 83, 1025-1032. [CrossRef] [PubMed]

69. Bauß, K.; Knapp, B.; Jores, P.; Roepman, R.; Kremer, H.; Wijk, E.V.; Märker, T.; Wolfrum, U. Phosphorylation of the Usher syndrome $1 G$ protein SANS controls Magi2-mediated endocytosis. Hum. Mol. Genet. 2014, 23, 3923-3942. [CrossRef] [PubMed]

70. Caberlotto, E.; Michel, V.; Foucher, I.; Bahloul, A.; Goodyear, R.J.; Pepermans, E.; Michalski, N.; Perfettini, I.; Alegria-Prévot, O.; Chardenoux, S.; et al. Usher type $1 \mathrm{G}$ protein sans is a critical component of the tip-link complex, a structure controlling actin polymerization in stereocilia. Proc. Natl. Acad. Sci. USA 2011, 108, 5825-5830. [CrossRef] [PubMed]

71. Maerker, T.; Van Wijk, E.; Overlack, N.; Kersten, F.F.; McGee, J.; Goldmann, T.; Sehn, E.; Roepman, R.; Walsh, E.J.; Kremer, H.; et al. A novel Usher protein network at the periciliary reloading point between molecular transport machineries in vertebrate photoreceptor cells. Hum. Mol. Genet. 2007, 17, 71-86. [CrossRef]

72. Overlack, N.; Kilic, D.; Bauß, K.; Märker, T.; Kremer, H.; van Wijk, E.; Wolfrum, U. Direct interaction of the Usher syndrome 1G protein SANS and myomegalin in the retina. Biochim. Biophys. Acta Bioenerg. 2011, 1813, 1883-1892. [CrossRef] [PubMed]

73. Sorusch, N.; Wunderlich, K.; Bauss, K.; Nagel-Wolfrum, K.; Wolfrum, U. Usher Syndrome Protein Network Functions in the Retina and their Relation to Other Retinal Ciliopathies. Adv. Exp. Med. Biol. 2014, 801, 527-533. [CrossRef] [PubMed]

74. Sorusch, N.; Bauß, K.; Plutniok, J.; Samanta, A.; Knapp, B.; Nagel-Wolfrum, K.; Wolfrum, U. Characterization of the ternary Usher syndrome SANS/ush2a/whirlin protein complex. Hum. Mol. Genet. 2017, 26, 1157-1172. [CrossRef] [PubMed]

75. Jacoszek, A.; Pollak, A.; Płoski, R.; Ołdak, M. Advances in genetic hearing loss: CIB2 gene. Eur. Arch. Oto-Rhino-Laryngol. 2016, 274, 1791-1795. [CrossRef] [PubMed]

76. Giese, A.P.J.; Tang, Y.-Q.; Sinha, G.P.; Bowl, M.; Goldring, A.C.; Parker, A.; Freeman, M.; Brown, S.D.M.; Riazuddin, S.; Fettiplace, R.; et al. CIB2 interacts with TMC1 and TMC2 and is essential for mechanotransduction in auditory hair cells. Nat. Commun. 2017, 8, 1-13. [CrossRef] [PubMed]

77. Michel, V.; Booth, K.T.; Patni, P.; Cortese, M.; Azaiez, H.; Bahloul, A.; Kahrizi, K.; Labbé, M.; Emptoz, A.; Lelli, A.; et al. CIB2, defective in isolated deafness, is key for auditory hair cell mechanotransduction and survival. EMBO Mol. Med. 2017, 9, 1711-1731. [CrossRef]

78. Wang, Y.; Li, J.; Yao, X.; Li, W.; Du, H.; Tang, M.; Xiong, W.; Chai, R.; Xu, Z. Loss of CIB2 Causes Profound Hearing Loss and Abolishes Mechanoelectrical Transduction in Mice. Front. Mol. Neurosci. 2017, 10, 401. [CrossRef]

79. Booth, K.; Kahrizi, K.; Babanejad, M.; Daghagh, H.; Bademci, G.; Arzhangi, S.; Zareabdollahi, D.; Duman, D.; El-Amraoui, A.; Tekin, M.; et al. Variants in CIB2 cause DFNB48 and not USH1J. Clin. Genet. 2018, 93, 812-821. [CrossRef]

80. Kimberling, W.J.; Weston, M.D.; Möller, C.; Davenport, S.L.; Shugart, Y.Y.; Priluck, I.A.; Martini, A.; Milani, M.; Smith, R.J. Localization of Usher syndrome type II to chromosome 1q. Genomics 1990, 7, 245-249. [CrossRef] 
81. Kimberling, W.J.; Weston, M.D.; Möller, C.; Van Aarem, A.; Cremers, C.W.R.J.; Sumegi, J.; Ing, P.S.; Connolly, C.; Martini, A.; Milani, M.; et al. Gene Mapping of Usher Syndrome Type IIa: Localization of the Gene to a 2.1-cM Segment on Chromosome 1q41. Am. J. Hum. Genet. 1995, 56, 216-223.

82. Dreyer, B.; Tranebjærg, L.; Brox, V.; Rosenberg, T.; Möller, C.; Beneyto, M.; Weston, M.D.; Kimberling, W.J.; Nilssen, Ø. A Common Ancestral Origin of the Frequent and Widespread 2299delG USH2A Mutation. Am. J. Hum. Genet. 2001, 69, 228-234. [CrossRef]

83. Aller, E.; Larrieu, L.; Jaijo, T.; Baux, D.; Espinós, C.; González-Candelas, F.; Nájera, C.; Palau, F.; Claustres, M.; Roux, A.-F.; et al. The USH2A c.2299delG mutation: Dating its common origin in a Southern European population. Eur. J. Hum. Genet. 2010, 18, 788-793. [CrossRef] [PubMed]

84. McGee, T.L.; Seyedahmadi, B.J.; Sweeney, M.O.; Dryja, T.P.; Berson, E.L. Novel mutations in the long isoform of the USH2A gene in patients with Usher syndrome type II or non-syndromic retinitis pigmentosa. J. Med. Genet. 2010, 47, 499-506. [CrossRef] [PubMed]

85. Rivolta, C.; Sweklo, E.A.; Berson, E.L.; Dryja, T.P. Missense Mutation in the USH2A Gene: Association with Recessive Retinitis Pigmentosa without Hearing Loss. Am. J. Hum. Genet. 2000, 66, 1975-1978. [CrossRef] [PubMed]

86. Eudy, J.D.; Weston, M.D.; Yao, S.; Hoover, D.M.; Rehm, H.L.; Ma-Edmonds, M.; Yan, D.; Ahmad, I.; Cheng, J.J.; Ayuso, C.; et al. Mutation of a Gene Encoding a Protein with Extracellular Matrix Motifs in Usher Syndrome Type IIa. Science 1998, 280, $1753-1757$. [CrossRef]

87. Weston, M.; Eudy, J.; Fujita, S.; Yao, S.-F.; Usami, S.; Cremers, C.; Greenburg, J.; Ramesar, R.; Martini, A.; Moller, C.; et al. Genomic Structure and Identification of Novel Mutations in Usherin, the Gene Responsible for Usher Syndrome Type IIa. Am. J. Hum. Genet. 2000, 66, 1199-1210. [CrossRef]

88. van Wijk, E.; Pennings, R.J.; te Brinke, H.; Claassen, A.; Yntema, H.G.; Hoefsloot, L.H.; Cremers, F.P.; Cremers, C.W.; Kremer, H. Identification of 51 Novel Exons of the Usher Syndrome Type 2A (USH2A) Gene That Encode Multiple Conserved Functional Domains and That Are Mutated in Patients with Usher Syndrome Type II. Am. J. Hum. Genet. 2004, 74, 738-744. [CrossRef] [PubMed]

89. Adato, A.; Lefèvre, G.; Delprat, B.; Michel, V.; Michalski, N.; Chardenoux, S.; Weil, D.; El-Amraoui, A.; Petit, C. Usherin, the defective protein in Usher syndrome type IIA, is likely to be a component of interstereocilia ankle links in the inner ear sensory cells. Hum. Mol. Genet. 2005, 14, 3921-3932. [CrossRef]

90. Michalski, N.; Michel, V.; Bahloul, A.; Lefèvre, G.; Barral, J.; Yagi, H.; Chardenoux, S.; Weil, D.; Martin, P.; Hardelin, J.-P.; et al. Molecular Characterization of the Ankle-Link Complex in Cochlear Hair Cells and Its Role in the Hair Bundle Functioning. J. Neurosci. 2007, 27, 6478-6488. [CrossRef] [PubMed]

91. Yang, J.; Wang, L.; Song, H.; Sokolov, M. Current Understanding of Usher Syndrome Type II. Front. Biosci. 2012, 17, 1165-1183. [CrossRef]

92. Liu, X.; Bulgakov, O.V.; Darrow, K.N.; Pawlyk, B.; Adamian, M.; Liberman, M.C.; Li, T. Usherin is required for maintenance of retinal photoreceptors and normal development of cochlear hair cells. Proc. Natl. Acad. Sci. USA 2007, 104, 4413-4418. [CrossRef]

93. Bhattacharya, G.; Miller, C.; Kimberling, W.J.; Jablonski, M.M.; Cosgrove, D. Localization and expression of usherin: A novel basement membrane protein defective in people with Usher's syndrome type Ila. Hear. Res. 2002, 163, 1-11. [CrossRef]

94. Weston, M.D.; Luijendijk, M.W.; Humphrey, K.D.; Möller, C.; Kimberling, W.J. Mutations in the VLGR1 Gene Implicate G-Protein Signaling in the Pathogenesis of Usher Syndrome Type II. Am. J. Hum. Genet. 2004, 74, 357-366. [CrossRef] [PubMed]

95. McMillan, D.R.; Kayes-Wandover, K.M.; Richardson, J.A.; White, P.C. Very Large G Protein-coupled Receptor-1, the Largest Known Cell Surface Protein, Is Highly Expressed in the Developing Central Nervous System. J. Biol. Chem. 2002, 277, 785-792. [CrossRef] [PubMed]

96. Sun, J.-P.; Li, R.; Ren, H.-Z.; Xu, A.-T.; Yu, X.; Xu, Z.-G. The Very Large G Protein Coupled Receptor (Vlgr1) in Hair Cells. J. Mol. Neurosci. 2012, 50, 204-214. [CrossRef]

97. Yagi, H.; Tokano, H.; Maeda, M.; Takabayashi, T.; Nagano, T.; Kiyama, H.; Fujieda, S.; Kitamura, K.; Sato, M. Vlgr1 is required for proper stereocilia maturation of cochlear hair cells. Genes Cells 2007, 12, 235-250. [CrossRef]

98. Ebermann, I.; Scholl, H.P.N.; Issa, P.C.; Becirovic, E.; Lamprecht, J.; Jurklies, B.; Millán, J.M.; Aller, E.; Mitter, D.; Bolz, H. A novel gene for Usher syndrome type 2: Mutations in the long isoform of whirlin are associated with retinitis pigmentosa and sensorineural hearing loss. Qual. Life Res. 2006, 121, 203-211. [CrossRef]

99. Van Wijk, E.; Van Der Zwaag, B.; Peters, T.; Zimmermann, U.; Brinke, H.T.; Kersten, F.F.; Märker, T.; Aller, E.; Hoefsloot, L.H.; Cremers, C.W.; et al. The DFNB31 gene product whirlin connects to the Usher protein network in the cochlea and retina by direct association with USH2A and VLGR1. Hum. Mol. Genet. 2006, 15, 751-765. [CrossRef]

100. Richard, E.M.; Santos-Cortez, R.L.P.; Faridi, R.; Rehman, A.U.; Lee, K.; Shahzad, M.; Acharya, A.; Khan, A.A.; Imtiaz, A.; Chakchouk, I.; et al. Global genetic insight contributed by consanguineous Pakistani families segregating hearing loss. Hum. Mutat. 2019, 40, 53-72. [CrossRef]

101. Tlili, A.; Charfedine, I.; Lahmar, I.; Benzina, Z.; Mohamed, B.A.; Weil, D.; Idriss, N.; Drira, M.; Masmoudi, S.; Ayadi, H. Identification of a novel frameshift mutation in the DFNB31/WHRN gene in a Tunisian consanguineous family with hereditary non-syndromic recessive hearing loss. Hum. Mutat. 2005, 25, 503. [CrossRef]

102. Audo, I.; Bujakowska, K.; Mohand-Saïd, S.; Tronche, S.; Lancelot, M.-E.; Antonio, A.; Germain, A.; Lonjou, C.; Carpentier, W.; Sahel, J.-A.; et al. A novel DFNB31 mutation associated with Usher type 2 syndrome showing variable degrees of auditory loss in a consanguineous Portuguese family. Mol. Vis. 2011, 17, 1598-1606. 
103. Besnard, T.; Vaché, C.; Baux, D.; Larrieu, L.; Abadie, C.; Blanchet, C.; Odent, S.; Blanchet, P.; Calvas, P.; Hamel, C.; et al. Non-USH2A mutations in USH2 patients. Hum. Mutat. 2012, 33, 504-510. [CrossRef] [PubMed]

104. Jiang, L.; Liang, X.; Li, Y.; Wang, J.; Zaneveld, J.E.; Wang, H.; Xu, S.; Wang, K.; Wang, B.; Chen, R.; et al. Comprehensive molecular diagnosis of 67 Chinese Usher syndrome probands: High rate of ethnicity specific mutations in Chinese USH patients. Orphanet J. Rare Dis. 2015, 10, 110. [CrossRef] [PubMed]

105. Yang, T.; Wei, X.; Chai, Y.; Li, L.; Wu, H. Genetic etiology study of the non-syndromic deafness in Chinese Hans by targeted next-generation sequencing. Orphanet J. Rare Dis. 2013, 8, 85. [CrossRef]

106. Ebrahim, S.; Ingham, N.J.; Lewis, M.A.; Rogers, M.J.; Cui, R.; Kachar, B.; Pass, J.C.; Steel, K.P. Alternative Splice Forms Influence Functions of Whirlin in Mechanosensory Hair Cell Stereocilia. Cell Rep. 2016, 15, 935-943. [CrossRef]

107. Yang, J.; Liu, X.; Zhao, Y.; Adamian, M.; Pawlyk, B.S.; Sun, X.; McMillan, D.R.; Liberman, M.C.; Li, T. Ablation of Whirlin Long Isoform Disrupts the USH2 Protein Complex and Causes Vision and Hearing Loss. PLoS Genet. 2010, 6, e1000955. [CrossRef]

108. Delprat, B.; Michel, V.; Goodyear, R.; Yamasaki, Y.; Michalski, N.; El-Amraoui, A.; Perfettini, I.; Legrain, P.; Richardson, G.; Hardelin, J.-P.; et al. Myosin XVa and whirlin, two deafness gene products required for hair bundle growth, are located at the stereocilia tips and interact directly. Hum. Mol. Genet. 2004, 14, 401-410. [CrossRef] [PubMed]

109. Holme, R.H.; Kiernan, B.W.; Brown, S.D.; Steel, K.P. Elongation of hair cell stereocilia is defective in the mouse mutant whirler. J. Comp. Neurol. 2002, 450, 94-102. [CrossRef]

110. Kikkawa, Y.; Mburu, P.; Morse, S.; Kominami, R.; Townsend, S.; Brown, S.D. Mutant analysis reveals whirlin as a dynamic organizer in the growing hair cell stereocilium. Hum. Mol. Genet. 2004, 14, 391-400. [CrossRef]

111. Manor, U.; Disanza, A.; Grati, M.; Andrade, L.; Lin, H.; Di Fiore, P.P.; Scita, G.; Kachar, B. Regulation of Stereocilia Length by Myosin XVa and Whirlin Depends on the Actin-Regulatory Protein Eps8. Curr. Biol. 2011, 21, 167-172. [CrossRef]

112. Kersten, F.F.J.; Van Wijk, E.; Van Reeuwijk, J.; Van Der Zwaag, B.; Märker, T.; Peters, T.A.; Katsanis, N.; Wolfrum, U.; Keunen, J.E.E.; Roepman, R.; et al. Association of Whirlin with Cav1.3 ( $\alpha 1 D)$ Channels in Photoreceptors, Defining a Novel Member of the Usher Protein Network. Investig. Opthalmol. Vis. Sci. 2010, 51, 2338-2346. [CrossRef]

113. Sankila, E.-M.; Pakarinen, L.; Kääriäinen, H.; Aittomäki, K.; Karjalainen, S.; Sistonen, P.; De La Chapelle, A. Assignment of an Usher syndrome type III (USH3) gene to chromosome 3q. Hum. Mol. Genet. 1995, 4, 93-98. [CrossRef] [PubMed]

114. Joensuu, T.; Hämäläinen, R.; Yuan, B.; Johnson, C.; Tegelberg, S.; Gasparini, P.; Zelante, L.; Pirvola, U.; Pakarinen, L.; Lehesjoki, A.-E.; et al. Mutations in a Novel Gene with Transmembrane Domains Underlie Usher Syndrome Type 3. Am. J. Hum. Genet. 2001, 69, 673-684. [CrossRef]

115. Adato, A.; Vreugde, S.; Joensuu, T.; Avidan, N.; Hamalainen, R.H.; Belenkiy, O.; Olender, T.; Bonne-Tamir, B.; Ben-Asher, E.; Espinos, C.; et al. USH3A transcripts encode clarin-1, a four-transmembrane-domain protein with a possible role in sensory synapses. Eur. J. Hum. Genet. 2002, 10, 339-350. [CrossRef]

116. Västinsalo, H.; Jalkanen, R.; Dinculescu, A.; Isosomppi, J.; Geller, S.; Flannery, J.G.; Hauswirth, W.W.; Sankila, E.-M. Alternative splice variants of the USH3A gene Clarin 1 (CLRN1). Eur. J. Hum. Genet. 2010, 19, 30-35. [CrossRef] [PubMed]

117. Ogun, O.; Zallocchi, M. Clarin-1 acts as a modulator of mechanotransduction activity and presynaptic ribbon assembly. J. Cell Biol. 2014, 207, 375-391. [CrossRef]

118. Geng, R.; Geller, S.F.; Hayashi, T.; Ray, C.A.; Reh, T.A.; Bermingham-McDonogh, O.; Jones, S.M.; Wright, C.G.; Melki, S.; Imanishi, Y.; et al. Usher syndrome IIIA gene clarin-1 is essential for hair cell function and associated neural activation. Hum. Mol. Genet. 2009, 18, 2748-2760. [CrossRef] [PubMed]

119. Zallocchi, M.; Meehan, D.T.; Delimont, D.; Askew, C.; Garige, S.; Gratton, M.A.; Rothermund-Franklin, C.A.; Cosgrove, D. Localization and expression of clarin-1, the Clrn1 gene product, in auditory hair cells and photoreceptors. Hear. Res. 2009, 255, 109-120. [CrossRef]

120. Eisenberger, T.; Slim, R.; Mansour, A.; Nauck, M.; Nürnberg, G.; Nürnberg, P.; Decker, C.; Dafinger, C.; Ebermann, I.; Bergmann, C.; et al. Targeted next-generation sequencing identifies a homozygous nonsense mutation in ABHD12, the gene underlying PHARC, in a family clinically diagnosed with Usher syndrome type 3. Orphanet J. Rare Dis. 2012, 7, 59. [CrossRef] [PubMed]

121. Puffenberger, E.G.; Jinks, R.N.; Sougnez, C.; Cibulskis, K.; Willert, R.A.; Achilly, N.P.; Cassidy, R.P.; Fiorentini, C.J.; Heiken, K.F.; Lawrence, J.J.; et al. Genetic Mapping and Exome Sequencing Identify Variants Associated with Five Novel Diseases. PLoS ONE 2012, 7, e28936. [CrossRef]

122. Vester, A.; Velez-Ruiz, G.; McLaughlin, H.M.; Program, T.N.C.S.; Lupski, J.R.; Talbot, K.; Vance, J.; Züchner, S.; Roda, R.H.; Fischbeck, K.H.; et al. A Loss-of-Function Variant in the Human Histidyl-tRNA Synthetase (HARS) Gene is Neurotoxic In Vivo. Hum. Mutat. 2013, 34, 191-199. [CrossRef]

123. Brozkova, D.S.; Deconinck, T.; Griffin, L.B.; Ferbert, A.; Haberlova, J.; Mazanec, R.; Lassuthova, P.; Roth, C.; Pilunthanakul, T.; Rautenstrauss, B.; et al. Loss of function mutations inHARScause a spectrum of inherited peripheral neuropathies. Brain 2015, 138, 2161-2172. [CrossRef] [PubMed]

124. Galatolo, D.; Kuo, M.E.; Mullen, P.; Meyer-Schuman, R.; Doccini, S.; Battini, R.; Lieto, M.; Tessa, A.; Filla, A.; Francklyn, C.; et al. Bi-allelic mutations in HARS1 severely impair histidyl-tRNA synthetase expression and enzymatic activity causing a novel multisystem ataxic syndrome. Hum. Mutat. 2020, 41, 1232-1237. [CrossRef] [PubMed]

125. Meyer-Schuman, R.; Antonellis, A. Evidence for a dominant-negative mechanism in HARS1-mediated peripheral neuropathy. FEBS J. 2021, 288, 91-94. [CrossRef] 
126. Khateb, S.; Zelinger, L.; Mizrahi-Meissonnier, L.; Ayuso, C.; Koenekoop, R.K.; Laxer, U.; Gross, M.; Banin, E.; Sharon, D. A homozygous nonsense CEP250 mutation combined with a heterozygous nonsense C2orf71 mutation is associated with atypical Usher syndrome. J. Med. Genet. 2014, 51, 460-469. [CrossRef]

127. Kubota, D.; Gocho, K.; Kikuchi, S.; Akeo, K.; Miura, M.; Yamaki, K.; Takahashi, H.; Kameya, S. CEP250 mutations associated with mild cone-rod dystrophy and sensorineural hearing loss in a Japanese family. Ophthalmic Genet. 2018, 39, 500-507. [CrossRef]

128. Khateb, S.; Kowalewski, B.; Bedoni, N.; Damme, M.; Pollack, N.; Saada, A.; Obolensky, A.; Ben-Yosef, T.; Gross, M.; Dierks, T.; et al. A homozygous founder missense variant in arylsulfatase $\mathrm{G}$ abolishes its enzymatic activity causing atypical Usher syndrome in humans. Genet. Med. 2018, 20, 1004-1012. [CrossRef] [PubMed]

129. Abad-Morales, V.; Navarro, R.; Burés-Jelstrup, A.; Pomares, E. Identification of a novel homozygous ARSG mutation as the second cause of Usher syndrome type 4. Am. J. Ophthalmol. Case Rep. 2020, 19, 100736. [CrossRef]

130. Peter, V.G.; Quinodoz, M.; Sadio, S.; Held, S.; Rodrigues, M.; Soares, M.; Sousa, A.B.; Santos, L.C.; Damme, M.; Rivolta, C. New clinical and molecular evidence linking mutations in ARSG to Usher syndrome type IV. Hum. Mutat. 2021, 42, 261-271. [CrossRef]

131. Namburi, P.; Ratnapriya, R.; Khateb, S.; Lazar, C.H.; Kinarty, Y.; Obolensky, A.; Erdinest, I.; Marks-Ohana, D.; Pras, E.; Ben-Yosef, T.; et al. Bi-allelic Truncating Mutations in CEP78, Encoding Centrosomal Protein 78, Cause Cone-Rod Degeneration with Sensorineural Hearing Loss. Am. J. Hum. Genet. 2016, 99, 777-784. [CrossRef] [PubMed]

132. Nikopoulos, K.; Farinelli, P.; Giangreco, B.; Tsika, C.; Royer-Bertrand, B.; Mbefo, M.K.; Bedoni, N.; Kjellström, U.; El Zaoui, I.; Di Gioia, S.A.; et al. Mutations in CEP78 Cause Cone-Rod Dystrophy and Hearing Loss Associated with Primary-Cilia Defects. Am. J. Hum. Genet. 2016, 99, 770-776. [CrossRef]

133. Fu, Q.; Xu, M.; Chen, X.; Sheng, X.; Yuan, Z.; Liu, Y.; Li, H.; Sun, Z.; Li, H.; Yang, L.; et al. CEP78is mutated in a distinct type of Usher syndrome. J. Med. Genet. 2017, 54, 190-195. [CrossRef] [PubMed]

134. Ahmed, Z.M.; Jaworek, T.J.; Sarangdhar, G.N.; Zheng, L.; Gul, K.; Khan, S.N.; Friedman, T.B.; Sisk, R.A.; Bartles, J.R.; Riazuddin, S.; et al. Inframe deletion of human ESPN is associated with deafness, vestibulopathy and vision impairment. J. Med. Genet. 2018, 55, 479-488. [CrossRef] [PubMed]

135. Wang, L.; Wei, B.; Fu, X.; Wang, Y.; Sui, Y.; Ma, J.; Gong, X.; Hao, J.; Xing, S. Identification of whirlin domains interacting with espin: A study of the mechanism of Usher syndrome type II. Mol. Med. Rep. 2019, 20, 5111-5117. [CrossRef] [PubMed]

136. Ebermann, I.; Phillips, J.B.; Liebau, M.C.; Koenekoop, R.K.; Schermer, B.; Lopez, I.; Schäfer, E.; Roux, A.-F.; Dafinger, C.; Bernd, A.; et al. PDZD7 is a modifier of retinal disease and a contributor to digenic Usher syndrome. J. Clin. Investig. 2010, 120, 1812-1823. [CrossRef]

137. García, C.F. Therapeutic Approaches and Development of Genomic Diagnostic Tools for Usher Syndrome; Universitat Politecnica de Valencia: Valencia, Spain, 2020.

138. Siemens, J.; Kazmierczak, P.; Reynolds, A.; Sticker, M.; Littlewood-Evans, A.; Müller, U. The Usher syndrome proteins cadherin 23 and harmonin form a complex by means of PDZ-domain interactions. Proc. Natl. Acad. Sci. USA 2002, 99, 14946-14951. [CrossRef] [PubMed]

139. Adato, A.; Michel, V.; Kikkawa, Y.; Reiners, J.; Alagramam, K.N.; Weil, D.; Yonekawa, H.; Wolfrum, U.; El-Amraoui, A.; Petit, C. Interactions in the network of Usher syndrome type 1 proteins. Hum. Mol. Genet. 2004, 14, 347-356. [CrossRef]

140. Reiners, J.; Märker, T.; Jürgens, K.; Reidel, B.; Wolfrum, U. Photoreceptor expression of the Usher syndrome type 1 protein protocadherin 15 (USH1F) and its interaction with the scaffold protein harmonin (USH1C). Mol. Vis. 2005, 11, 347-355.

141. Senften, M.; Schwander, M.; Kazmierczak, P.; Lillo, C.; Shin, J.-B.; Hasson, T.; Géléoc, G.S.G.; Gillespie, P.G.; Williams, D.; Holt, J.R.; et al. Physical and Functional Interaction between Protocadherin 15 and Myosin VIIa in Mechanosensory Hair Cells. J. Neurosci. 2006, 26, 2060-2071. [CrossRef]

142. Dulon, D.; Papal, S.; Patni, P.; Cortese, M.; Vincent, M.; Tertrais, M.; Emptoz, A.; Tlili, A.; Bouleau, Y.; Michel, V.; et al. Clarin-1 gene transfer rescues auditory synaptopathy in model of Usher syndrome. J. Clin. Investig. 2018, 128, 3382-3401. [CrossRef]

143. Grillet, N.; Xiong, W.; Reynolds, A.; Kazmierczak, P.; Sato, T.; Lillo, C.; Dumont, R.A.; Hintermann, E.; Sczaniecka, A.; Schwander, M.; et al. Harmonin Mutations Cause Mechanotransduction Defects in Cochlear Hair Cells. Neuron 2009, 62, 375-387. [CrossRef] [PubMed]

144. Bahloul, A.; Michel, V.; Hardelin, J.-P.; Nouaille, S.; Hoos, S.; Houdusse, A.; England, P.; Petit, C. Cadherin-23, myosin VIIa and harmonin, encoded by Usher syndrome type I genes, form a ternary complex and interact with membrane phospholipids. Hum. Mol. Genet. 2010, 19, 3557-3565. [CrossRef] [PubMed]

145. Blanco-Sánchez, B.; Clément, A.; Junior, J.F.; Washbourne, P.; Westerfield, M. Usher protein complexes preassemble at the endoplasmic reticulum and are required for trafficking and ER homeostasis. Dis. Model. Mech. 2014, 7, 547-559. [CrossRef]

146. Pan, L.; Yan, J.; Wu, L.; Zhang, M. Assembling stable hair cell tip link complex via multidentate interactions between harmonin and cadherin. Proc. Natl. Acad. Sci. USA 2009, 106, 5575-5580. [CrossRef]

147. Zheng, L.; Zheng, J.; Whitlon, D.S.; García-Añoveros, J.; Bartles, J.R. Targeting of the Hair Cell Proteins Cadherin 23, Harmonin, Myosin XVa, Espin, and Prestin in an Epithelial Cell Model. J. Neurosci. 2010, 30, 7187-7201. [CrossRef]

148. Sotomayor, M.; Weihofen, W.A.; Gaudet, R.; Corey, D.P. Structure of a force-conveying cadherin bond essential for inner-ear mechanotransduction. Nat. Cell Biol. 2012, 492, 128-132. [CrossRef] [PubMed]

149. Frolenkov, G.I.; Belyantseva, I.A.; Friedman, T.B.; Griffith, A.J. Genetic insights into the morphogenesis of inner ear hair cells. Nat. Rev. Genet. 2004, 5, 489-498. [CrossRef] 
150. Petit, C.; Richardson, G.P. Linking genes underlying deafness to hair-bundle development and function. Nat. Neurosci. 2009, 12, 703-710. [CrossRef]

151. Bergmann, C. Educational paper. Eur. J. Nucl. Med. Mol. Imaging 2011, 171, 1285-1300. [CrossRef]

152. Reiter, J.F.; Leroux, M.R. Genes and molecular pathways underpinning ciliopathies. Nat. Rev. Mol. Cell Biol. 2017, 18, 533-547. [CrossRef]

153. Shivanna, M.; Anand, M.; Chakrabarti, S.; Khanna, H. Ocular Ciliopathies: Genetic and Mechanistic Insights into Developing Therapies. Curr. Med. Chem. 2019, 26, 3120-3131. [CrossRef]

154. Bujakowska, K.M.; Liu, Q.; Pierce, E.A. Photoreceptor Cilia and Retinal Ciliopathies. Cold Spring Harb. Perspect. Biol. 2017, 9, a028274. [CrossRef]

155. Gerth-Kahlert, C.; Koller, S. Retinale Ziliopathien. Klinische Monatsblätter Augenheilkunde 2018, 235, 264-272. [CrossRef] [PubMed]

156. Tsang, S.H.; Aycinena, A.R.P.; Sharma, T. Ciliopathy: Usher Syndrome. In Advances in Experimental Medicine and Biology; Springer: Berlin/Heidelberg, Germany, 2018; Volume 1085, pp. 167-170.

157. Bonneau, D.; Raymond, F.; Kremer, C.; Klossek, J.M.; Kaplan, J.; Patte, F. Usher syndrome type I associated with bronchiectasis and immotile nasal cilia in two brothers. J. Med. Genet. 1993, 30, 253-254. [CrossRef]

158. Ribeiro, J.C.; Oliveiros, B.; Pereira, P.; António, N.; Hummel, T.; Paiva, A.; Silva, E.D. Accelerated age-related olfactory decline among type 1 Usher patients. Sci. Rep. 2016, 6, 28309. [CrossRef] [PubMed]

159. Zrada, S.E.; Braat, K.; Doty, R.L.; Laties, A.M. Olfactory loss in Usher syndrome: Another sensory deficit? Am. J. Med. Genet. 1996, 64, 602-603. [CrossRef]

160. Aparisi, M.J.; García-García, G.; Aller, E.; Sequedo, M.D.; de la Camara, C.M.-F.; Rodrigo, R.; Armengot, M.; Cortijo, J.; Milara, J.; Díaz-Llopis, M.; et al. Study of USH1 Splicing Variants through Minigenes and Transcript Analysis from Nasal Epithelial Cells. PLoS ONE 2013, 8, e57506. [CrossRef]

161. Ciardo, M.G.; Borderia, D.A.; Cuesta, N.; Valente, P.; Camprubí-Robles, M.; Yang, J.; Planells-Cases, R.; Ferrer-Montiel, A. Whirlin increases TRPV1 channel expression and cellular stability. Biochim. Biophys. Acta Bioenerg. 2016, 1863, 115-127. [CrossRef] [PubMed]

162. Hunter, D.G.; Fishman, G.A.; Mehta, R.S.; Kretzer, F.L. Abnormal Sperm and Photoreceptor Axonemes in Usher's Syndrome. Arch. Ophthalmol. 1986, 104, 385-389. [CrossRef]

163. Frenzel, H.; Bohlender, J.; Pinsker, K.; Wohlleben, B.; Tank, J.; Lechner, S.G.; Schiska, D.; Jaijo, T.; Rüschendorf, F.; Saar, K.; et al. A Genetic Basis for Mechanosensory Traits in Humans. PLoS Biol. 2012, 10, e1001318. [CrossRef]

164. Moshourab, R.; Bégay, V.; Wetzel, C.; Walcher, J.; Middleton, S.; Gross, M.; Lewin, G.R. Congenital deafness is associated with specific somatosensory deficits in adolescents. Sci. Rep. 2017, 7, 4251. [CrossRef]

165. Schwaller, F.; Bégay, V.; García-García, G.; Taberner, F.J.; Moshourab, R.; McDonald, B.; Docter, T.; Kühnemund, J.; Ojeda-Alonso, J.; Paricio-Montesinos, R.; et al. USH2A is a Meissner's corpuscle protein necessary for normal vibration sensing in mice and humans. Nat. Neurosci. 2021, 24, 74-81. [CrossRef]

166. Géléoc, G.G.; El-Amraoui, A. Disease mechanisms and gene therapy for Usher syndrome. Hear. Res. 2020, 394, 107932. [CrossRef] [PubMed]

167. Lentz, J.J.; Gordon, W.C.; Farris, H.E.; Macdonald, G.H.; Cunningham, D.E.; Robbins, C.A.; Tempel, B.L.; Bazan, N.G.; Rubel, E.W.; Oesterle, E.C.; et al. Deafness and retinal degeneration in a novel USH1C knock-in mouse model. Dev. Neurobiol. 2010, 70, 253-267. [CrossRef] [PubMed]

168. Yao, L.; Zhang, L.; Qi, L.-S.; Liu, W.; An, J.; Wang, B.; Xue, J.-H.; Zhang, Z.-M. The Time Course of Deafness and Retinal Degeneration in a Kunming Mouse Model for Usher Syndrome. PLoS ONE 2016, 11, e0155619. [CrossRef] [PubMed]

169. Dona, M.; Slijkerman, R.; Lerner, K.; Broekman, S.; Wegner, J.; Howat, T.; Peters, T.; Hetterschijt, L.; Boon, N.; de Vrieze, E.; et al. Usherin defects lead to early-onset retinal dysfunction in zebrafish. Exp. Eye Res. 2018, 173, 148-159. [CrossRef]

170. McGee, J.; Goodyear, R.J.; McMillan, D.R.; Stauffer, E.A.; Holt, J.R.; Locke, K.G.; Birch, D.G.; Legan, P.K.; White, P.C.; Walsh, E.J.; et al. The Very Large G-Protein-Coupled Receptor VLGR1: A Component of the Ankle Link Complex Required for the Normal Development of Auditory Hair Bundles. J. Neurosci. 2006, 26, 6543-6553. [CrossRef]

171. Blanco-Sánchez, B.; Clément, A.; Phillips, J.; Westerfield, M. Zebrafish models of human eye and inner ear diseases. Meth. Cell Biol. 2017, 138, 415-467. [CrossRef]

172. Han, S.; Liu, X.; Xie, S.; Gao, M.; Liu, F.; Yu, S.; Sun, P.; Wang, C.; Archacki, S.; Lu, Z.; et al. Knockout of ush2a gene in zebrafish causes hearing impairment and late onset rod-cone dystrophy. Qual. Life Res. 2018, 137, 779-794. [CrossRef]

173. Ernest, S.; Rauch, G.-J.; Haffter, P.; Geisler, R.; Petit, C.; Nicolson, T. Mariner is defective in myosin VIIA: A zebrafish model for human hereditary deafness. Hum. Mol. Genet. 2000, 9, 2189-2196. [CrossRef]

174. Wasfy, M.M.; Matsui, J.I.; Miller, J.; Dowling, J.E.; Perkins, B.D. myosin 7aa-/- mutant zebrafish show mild photoreceptor degeneration and reduced electroretinographic responses. Exp. Eye Res. 2014, 122, 65-76. [CrossRef]

175. Gibson, F.; Walsh, J.P.; Mburu, P.; Varela, A.; Brown, K.A.; Antonio, M.R.D.S.; Beisel, K.W.; Steel, K.P.; Brown, S.D.M. A type VII myosin encoded by the mouse deafness gene shaker-1. Nat. Cell Biol. 1995, 374, 62-64. [CrossRef]

176. Mburu, P.; Liu, X.Z.; Walsh, J.; Saw, D.; Cope, J.; Gibson, F.; Kendrick-Jones, J.; Steel, K.; Brown, S. Mutation analysis of the mouse myosin VIIA deafness gene. Genes Funct. 1997, 1, 191-203. [CrossRef]

177. Rhodes, C.R.; Hertzano, R.; Fuchs, H.; Bell, R.E.; de Angelis, M.H.; Steel, K.P.; Avraham, K.B. A Myo7a mutation cosegregates with stereocilia defects and low-frequency hearing impairment. Mamm. Genome 2004, 15, 686-697. [CrossRef] 
178. Schwander, M.; Sczaniecka, A.; Grillet, N.; Bailey, J.S.; Avenarius, M.; Najmabadi, H.; Steffy, B.M.; Federe, G.C.; Lagler, E.A.; Banan, R.; et al. A Forward Genetics Screen in Mice Identifies Recessive Deafness Traits and Reveals That Pejvakin Is Essential for Outer Hair Cell Function. J. Neurosci. 2007, 27, 2163-2175. [CrossRef] [PubMed]

179. Schwander, M.; Lopes, V.; Sczaniecka, A.; Gibbs, D.; Lillo, C.; Delano, D.; Tarantino, L.M.; Wiltshire, T.; Williams, D.S.; Müller, U. A Novel Allele of Myosin VIIa Reveals a Critical Function for the C-Terminal FERM Domain for Melanosome Transport in Retinal Pigment Epithelial Cells. J. Neurosci. 2009, 29, 15810-15818. [CrossRef] [PubMed]

180. Miller, K.A.; Williams, L.H.; Rose, E.; Kuiper, M.; Dahl, H.-H.M.; Manji, S.S.M. Inner Ear Morphology Is Perturbed in Two Novel Mouse Models of Recessive Deafness. PLoS ONE 2012, 7, e51284. [CrossRef] [PubMed]

181. Calabro, K.R.; Boye, S.L.; Choudhury, S.; Fajardo, D.; Peterson, J.J.; Li, W.; Crosson, S.M.; Kim, M.-J.; Ding, D.; Salvi, R.; et al. A Novel Mouse Model of MYO7A USH1B Reveals Auditory and Visual System Haploinsufficiencies. Front. Neurosci. 2019, 13, 1255. [CrossRef]

182. Phillips, J.B.; Blanco-Sanchez, B.; Lentz, J.J.; Tallafuss, A.; Khanobdee, K.; Sampath, S.; Jacobs, Z.G.; Han, P.F.; Mishra, M.; Titus, T.A.; et al. Harmonin (Ush1c) is required in zebrafish Müller glial cells for photoreceptor synaptic development and function. Dis. Model. Mech. 2011, 4, 786-800. [CrossRef] [PubMed]

183. Johnson, K.R. Mouse models of USH1C and DFNB18: Phenotypic and molecular analyses of two new spontaneous mutations of the Ush1c gene. Hum. Mol. Genet. 2003, 12, 3075-3086. [CrossRef] [PubMed]

184. Lefèvre, G.; Michel, V.; Weil, D.; Lepelletier, L.; Bizard, E.; Wolfrum, U.; Hardelin, J.-P.; Petit, C. A core cochlear phenotype in USH1 mouse mutants implicates fibrous links of the hair bundle in its cohesion, orientation and differential growth. Development 2008, 135, 1427-1437. [CrossRef]

185. Tian, C.; Liu, X.Z.; Han, F.; Yu, H.; Longo-Guess, C.; Yang, B.; Lu, C.; Yan, D.; Zheng, Q.Y. Ush1c gene expression levels in the ear and eye suggest different roles for Ush1c in neurosensory organs in a new Ush1c knockout mouse. Brain Res. 2010, 1328, 57-70. [CrossRef]

186. Lentz, J.; Pan, F.; Ng, S.S.; Deininger, P.; Keats, B. Ush1c216A knock-in mouse survives Katrina. Mutat. Res. Mol. Mech. Mutagen. 2007, 616, 139-144. [CrossRef]

187. Trouillet, A.; Dubus, E.; Dégardin, J.; Estivalet, A.; Ivkovic, I.; Godefroy, D.; García-Ayuso, D.; Simonutti, M.; Sahly, I.; Sahel, J.A.; et al. Cone degeneration is triggered by the absence of USH1 proteins but prevented by antioxidant treatments. Sci. Rep. 2018, 8 , 1-12. [CrossRef]

188. Söllner, C.; Rauch, G.-J.; Siemens, J.; Geisler, R.; Schuster, S.C.; the Tübingen 2000 Screen Consortium; Müller, U.; Nicolson, T. Mutations in cadherin 23 affect tip links in zebrafish sensory hair cells. Nat. Cell Biol. 2004, 428, 955-959. [CrossRef] [PubMed]

189. Glover, G.; Mueller, K.P.; Söllner, C.; Neuhauss, S.C.F.; Nicolson, T. The Usher gene cadherin 23 is expressed in the zebrafish brain and a subset of retinal amacrine cells. Molec. Vision 2012, 18, 2309-2322. [CrossRef] [PubMed]

190. Di-Palma, F.; Holme, R.H.; Bryda, E.C.; Belyantseva, I.A.; Pellegrino, R.; Kachar, B.; Steel, K.P.; Noben-Trauth, K. Mutations in $\mathrm{Cdh} 23$, encoding a new type of cadherin, cause stereocilia disorganization in waltzer, the mouse model for Usher syndrome type 1D. Nat. Genet. 2001, 27, 103-107. [CrossRef]

191. Seiler, C.; Finger-Baier, K.C.; Rinner, O.; Makhankov, Y.V.; Schwarz, H.; Neuhauss, S.C.F.; Nicolson, T. Duplicated genes with split functions: Independent roles of protocadherin15 orthologues in zebrafish hearing and vision. Development 2005, 132, 615-623. [CrossRef] [PubMed]

192. Geng, R.; Sotomayor, M.; Kinder, K.J.; Gopal, S.; Gerka-Stuyt, J.; Chen, D.H.-C.; Hardisty-Hughes, R.E.; Ball, G.; Parker, A.; Gaudet, R.; et al. Noddy, a mouse harboring a missense mutation in protocadherin-15, reveals the impact of disrupting a critical interaction site between tip-link cadherins in inner ear hair cells. J. Neurosci. 2013, 33, 4395-4404. [CrossRef]

193. Kikkawa, Y.; Shitara, H.; Wakana, S.; Kohara, Y.; Takada, T.; Okamoto, M.; Taya, C.; Kamiya, K.; Yoshikawa, Y.; Tokano, H.; et al. Mutations in a New Scaffold Protein Sans Cause Deafness in Jackson Shaker Mice. Hum. Mol. Genet. 2003, 12, 453-461. [CrossRef]

194. Lane, P.W. WHIRLER MICE: A Recessive Behavior Mutation in Linkage Group VIII. J. Hered. 1963, 54, 263-266. [CrossRef] [PubMed]

195. Fleming, J.; Rogers, M.; Brown, S.; Steel, K. Linkage Analysis of the whirler Deafness Gene on Mouse Chromosome 4. Genome 1994, 21, 42-48. [CrossRef]

196. Rogers, M.J.; Fleming, J.; Kiernan, B.W.; Mburu, P.; Varela, A.; Brown, S.D.; Steel, K.P. Genetic mapping of the whirler mutation. Mamm. Genome 1999, 10, 513-519. [CrossRef]

197. Paige, A.J.; Kiernan, B.W.; Varela, A.; Rogers, M.J.; Hughes, D.; Steel, K.P.; Brown, S.D. A deletion on chromosome 4 cosegregates with the whirler deafness mutation: Exclusion of Orm1 as a candidate. Mamm. Genome 2000, 11, 51-57. [CrossRef] [PubMed]

198. Gopal, S.R.; Chen, D.H.-C.; Chou, S.-W.; Zang, J.; Neuhauss, S.C.; Stepanyan, R.; McDermott, B.M.; Alagramam, K.N. Zebrafish Models for the Mechanosensory Hair Cell Dysfunction in Usher Syndrome 3 Reveal That Clarin-1 Is an Essential Hair Bundle Protein. J. Neurosci. 2015, 35, 10188-10201. [CrossRef]

199. Geller, S.F.; Guerin, K.I.; Visel, M.; Pham, A.; Lee, E.S.; Dror, A.A.; Avraham, K.B.; Hayashi, T.; Ray, C.A.; Reh, T.A.; et al. CLRN1 Is Nonessential in the Mouse Retina but Is Required for Cochlear Hair Cell Development. PLoS Genet. 2009, 5, e1000607. [CrossRef] [PubMed]

200. Geng, R.; Melki, S.; Chen, D.H.-C.; Tian, G.; Furness, D.N.; Oshima-Takago, T.; Neef, J.; Moser, T.; Askew, C.; Horwitz, G.; et al. The Mechanosensory Structure of the Hair Cell Requires Clarin-1, a Protein Encoded by Usher Syndrome III Causative Gene. J. Neurosci. 2012, 32, 9485-9498. [CrossRef] 
201. Geng, R.; Omar, A.; Gopal, S.R.; Chen, D.H.-C.; Stepanyan, R.; Basch, M.L.; Dinculescu, A.; Furness, D.N.; Saperstein, D.; Hauswirth, W.; et al. Modeling and Preventing Progressive Hearing Loss in Usher Syndrome III. Sci. Rep. 2017, 7, 1-15. [CrossRef]

202. Xu, L.; Bolch, S.N.; Santiago, C.P.; Dyka, F.M.; Akil, O.; Lobanova, E.; Wang, Y.; Martemyanov, K.A.; Hauswirth, W.W.; Smith, W.C.; et al. Clarin-1 expression in adult mouse and human retina highlights a role of Müller glia in Usher syndrome. J. Pathol. 2020, 250, 195-204. [CrossRef]

203. Vaché, C.; Besnard, T.; le Berre, P.; García-García, G.; Baux, D.; Larrieu, L.; Abadie, C.; Blanchet, C.; Bolz, H.J.; Millan, J.; et al. Usher syndrome type 2 caused by activation of an USH2A pseudoexon: Implications for diagnosis and therapy. Hum. Mutat. 2012, 33, 104-108. [CrossRef]

204. Liquori, A.; Vaché, C.; Baux, D.; Blanchet, C.; Hamel, C.P.; Malcolm, S.; Koenig, M.; Claustres, M.; Roux, A.-F. WholeUSH2AGene Sequencing Identifies Several New Deep Intronic Mutations. Hum. Mutat. 2016, 37, 184-193. [CrossRef]

205. Khan, A.O.; Becirovic, E.; Betz, C.; Neuhaus, C.; Altmüller, J.; Riedmayr, L.M.; Motameny, S.; Nürnberg, G.; Nürnberg, P.; Bolz, H.J. A deep intronic CLRN1 (USH3A) founder mutation generates an aberrant exon and underlies severe Usher syndrome on the Arabian Peninsula. Sci. Rep. 2017, 7, 1-10. [CrossRef]

206. Le Guédard, S.; Faugère, V.; Malcolm, S.; Claustres, M.; Roux, A.-F. Large genomic rearrangements within the PCDH15 gene are a significant cause of USH1F syndrome. Mol. Vis. 2007, 13, 102-107. [PubMed]

207. Aller, E.; Jaijo, T.; García-García, G.; Aparisi, M.J.; Blesa, D.; Díaz-Llopis, M.; Ayuso, C.; Millán, J.M. Identification of Large Rearrangements of thePCDH15Gene by Combined MLPA and a CGH: Large Duplications Are Responsible for Usher Syndrome. Investig. Opthalmol. Vis. Sci. 2010, 51, 5480-5485. [CrossRef] [PubMed]

208. García-García, G.; Aller, E.; Jaijo, T.; Aparisi, M.J.; Larrieu, L.; Faugère, V.; Blanco-Kelly, F.; Ayuso, C.; Roux, A.-F.; Millán, J.M. Novel deletions involving the USH2A gene in patients with Usher syndrome and retinitis pigmentosa. Mol. Vis. 2014, 20, 1398-1410.

209. Vaché, C.; Puechberty, J.; Faugère, V.; Darmaisin, F.; Liquori, A.; Baux, D.; Blanchet, C.; Garcia-Garcia, G.; Meunier, I.; Pellestor, F.; et al. A 4.6 Mb Inversion Leading to PCDH15-LINC00844 and BICC1-PCDH15 Fusion Transcripts as a New Pathogenic Mechanism Implicated in Usher Syndrome Type 1. Front. Genet. 2020, 11, 623. [CrossRef] [PubMed]

210. Yu, D.; Zou, J.; Chen, Q.; Zhu, T.; Sui, R.; Yang, J. Structural modeling, mutation analysis, and in vitro expression of usherin, a major protein in inherited retinal degeneration and hearing loss. Comput. Struct. Biotechnol. J. 2020, 18, 1363-1382. [CrossRef]

211. McMillan, D.; White, P.C. Loss of the transmembrane and cytoplasmic domains of the very large G-protein-coupled receptor-1 (VLGR1 or Mass1) causes audiogenic seizures in mice. Mol. Cell. Neurosci. 2004, 26, 322-329. [CrossRef]

212. Pérez-Carro, R.; Blanco-Kelly, F.; Galbis-Martínez, L.; García-García, G.; Aller, E.; García-Sandoval, B.; Mínguez, P.; Corton, M.; Mahíllo-Fernández, I.; Martín-Mérida, I.; et al. Unravelling the pathogenic role and genotype-phenotype correlation of the USH2A p.(Cys759Phe) variant among Spanish families. PLoS ONE 2018, 13, e0199048. [CrossRef]

213. Doucette, L.; Merner, N.; Cooke, S.; Ives, E.; Galutira, D.; Walsh, V.; Walsh, T.; MacLaren, L.; Cater, T.; Fernandez, B.; et al. Profound, prelingual nonsyndromic deafness maps to chromosome 10q21 and is caused by a novel missense mutation in the Usher syndrome type IF gene PCDH15. Eur. J. Hum. Genet. 2008, 17, 554-564. [CrossRef]

214. Mchugh, R.K.; Friedman, R.A. Genetics of hearing loss: Allelism and modifier genes produce a phenotypic continuum. Anat. Rec. Part. A Discov. Mol. Cell. Evol. Biol. 2006, 288A, 370-381. [CrossRef]

215. Khateb, S.; Mohand-Saïd, S.; Nassisi, M.; Bonnet, C.; Roux, A.-F.; Andrieu, C.; Antonio, A.; Condroyer, C.; Zeitz, C.; Devisme, C.; et al. Phenotypic characteristics of rod-cone dystrophy associated with myo7a mutations in a large french cohort. Retina 2020, 40, 1603-1615. [CrossRef] [PubMed]

216. Maguire, A.M.; Russell, S.; Wellman, J.A.; Chung, D.C.; Yu, Z.-F.; Tillman, A.; Wittes, J.; Pappas, J.; Elci, O.; Marshall, K.A.; et al. Efficacy, Safety, and Durability of Voretigene Neparvovec-rzyl in RPE65 Mutation-Associated Inherited Retinal Dystrophy. Ophthalmology 2019, 126, 1273-1285. [CrossRef]

217. Lentz, J.J.; Jodelka, F.M.; Hinrich, A.J.; McCaffrey, K.E.; Farris, H.E.; Spalitta, M.J.; Bazan, N.G.; Duelli, D.M.; Rigo, F.; Hastings, M.L. Rescue of hearing and vestibular function by antisense oligonucleotides in a mouse model of human deafness. Nat. Med. 2013, 19, 345-350. [CrossRef]

218. Slijkerman, R.W.; Vaché, C.; Dona, M.; García-García, G.; Claustres, M.; Hetterschijt, L.; Peters, T.A.; Hartel, B.P.; Pennings, R.J.; Millan, J.M.; et al. Antisense Oligonucleotide-based Splice Correction for USH2A-associated Retinal Degeneration Caused by a Frequent Deep-intronic Mutation. Mol. Ther. Nucleic Acids 2016, 5, e381. [CrossRef]

219. Stein, C.A.; Castanotto, D. FDA-Approved Oligonucleotide Therapies in 2017. Mol. Ther. 2017, 25, 1069-1075. [CrossRef] [PubMed] 